Portland State University

PDXScholar

1973

\title{
Sickle Cell Anemia : a Psychosocial Study of Attitudes and Effect
}

\author{
Sharon Ann Goddard \\ Portland State University \\ Marian Genita Gilmore \\ Portland State University
}

Follow this and additional works at: https://pdxscholar.library.pdx.edu/open_access_etds

Part of the Social Work Commons

Let us know how access to this document benefits you.

\section{Recommended Citation}

Goddard, Sharon Ann and Gilmore, Marian Genita, "Sickle Cell Anemia : a Psychosocial Study of Attitudes and Effect" (1973). Dissertations and Theses. Paper 2055.

https://doi.org/10.15760/etd.2054

This Thesis is brought to you for free and open access. It has been accepted for inclusion in Dissertations and Theses by an authorized administrator of PDXScholar. Please contact us if we can make this document more accessible: pdxscholar@pdx.edu. 
AN ABSTRACT OF THE THESIS OF Marian G. G1lmore and Sharon A. Goddard for the Masters Degree of Social Work presented May 18, 1973.

Title: Sickle Cell Anemia: A Psychosocial Study of Attitudes and Effect.

APPROVED BY MEMBERS OF THE THESIS COMMITTEE:

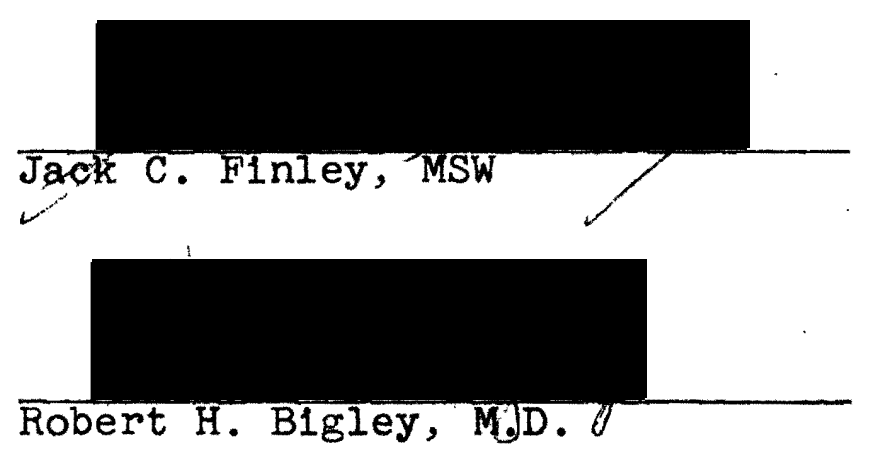

This research study was focused on two broad areas of exploration. The first area deals with the identification of various factors affecting a family when a family member has the anemia or symptomatic form of sickle cell disease. Data obtained from a personally administered questionnaire (Form A), enabled the researchers to determine if genetic counseling had been offered and recelved, and if this counseling was considered helpful by the respondents. In addition to this, data was collected on several demographic variables, including sex and age of patient, family income, 
religion, education, ethnic group, living arrangements and occupation, and response to and knowledge of sickle cell anemia.

The second broad area of exploration investigated the awareness and general knowledge of sickle cell disease among a quota non-probability sampling of a selected population in Portland, Oregon. The sample was composed of ninety-nine respondents, forty-flve blacks and forty-seven whites. Information was collected by personal contact through a questionnalre (Form B) to determine if there was any difference between black and white attitudes and knowledge concerning sickle cell anemia.

Data analysis indicates that there is no statistically significant difference between black and white respondents to Questionnaire Form B. Responses tended to be uniformly similar concerning both awareness of and attitudes toward sickle cell anemia.

Limitations of the study must be considered as follows: (1) the number of respondents to Questionnalre Form A was limited since only five families were avallable for participation in the study; (2) data collection was based on subjective recall without further investigation into the accuracy of the reports; (3) a non-probability sampling for Questionnaire Form $B$ creates the risk of 
obtaining a blased sample, and (4) the study did not deal with the effects of demographic variables. 
SICKLE CELI ANEMIA:

A PSYCHOSOCIAL STUDY OF ATTITUDES AND EFFECT

\author{
by \\ Marian G. Gilmore \\ and \\ Sharon A. Goddard
}

A thesis submitted in partial fulfiliment of the requirements for the degree of

MASTER OF SOCIAL WORK

$\because$ Portland State University

1973 
TO THE OFFICE OF GRADUATE STUDIES:

The members of the committee approve the thesis of Marian Genita Gilmore and Sharon Ann Goddard presented May $18,1973$.
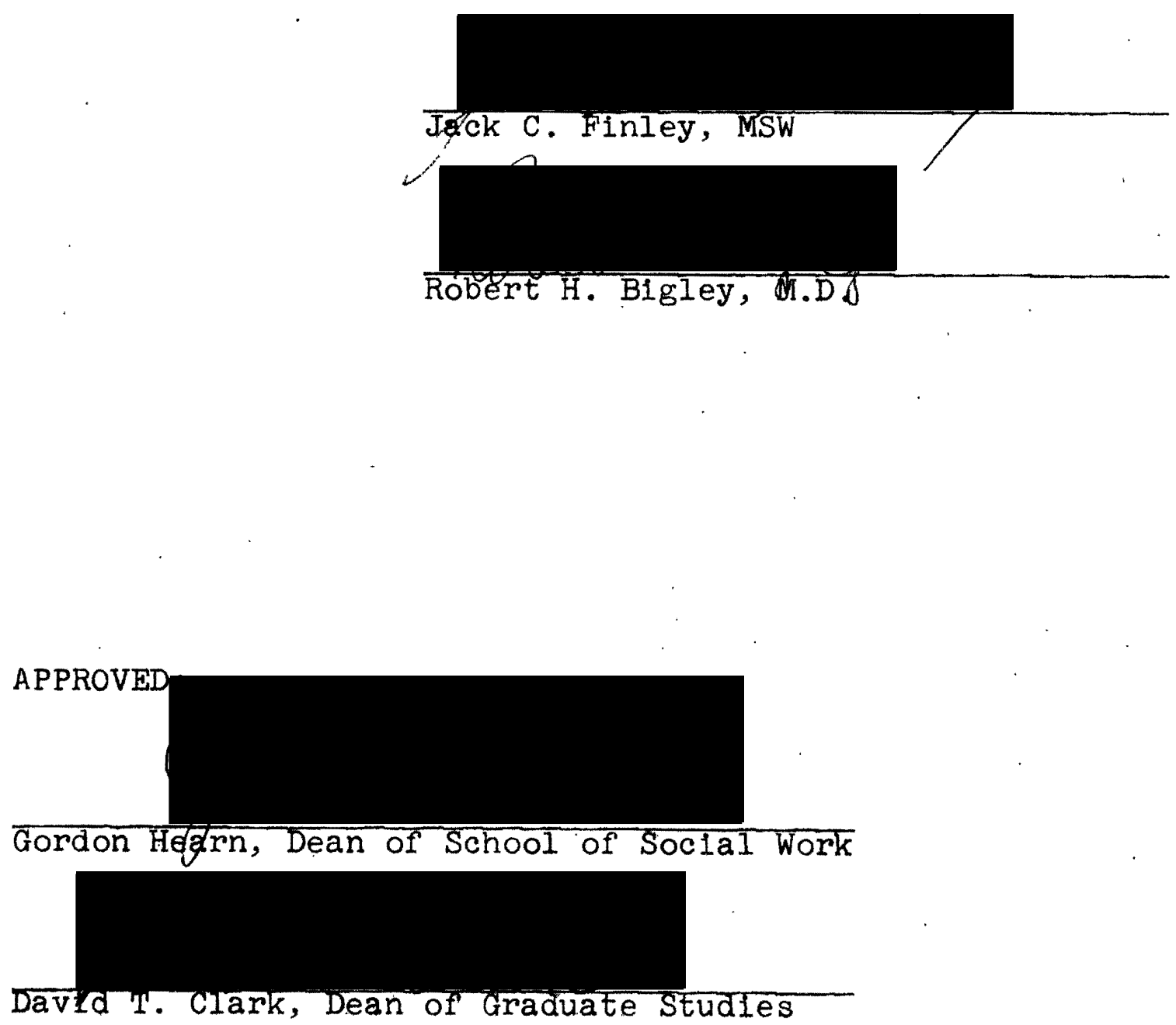

May 18, 1973 


\section{ACKNOWLEDGMENTS}

Special acknowledgment and thanks are extended to Jack Finley and Robert Bigley who acted as advisors to this undertaking. Their help and support are deeply appreclated. We are also grateful for the time and expertise of Dr. Dean Clarkson who consulted with us on this project. Further acknowledgment is extended to Sandra Ford for her extra effort in helping us make contact with target families. And finally, special thanks are extended to Debra and One1ta Ballard, and Skip Goddard for their continued support and unfaltering falth, and to David Knott for his tolerant encouragement, understanding and Invaluable technical advice. 
TABLE OF CONTENTS

PAGE

ACKNOWLEDGMENTS . . . . . . . . . . . . . 111

LIST OF TABLES . . . . . . . . . . . . . . v v1

LIST OF FIGURES . . . . . . . . . . . . . V111 CHAPTER

I. INTRODUCTION .................... . . I

Areas of Focus ............... 1

SICKLE CELL ANEMIA . . . . . . . . . . 3

An Introduction . . . . . . . . . . 3

Clinical Manifestations ......... 4

Sickle Cell Trait ............ 6

Etlology . . . . . . . . . . . . 7

Treatment ............... . 9

II. REVIEW OF THE LITERATURE . . . . . . . . . 10

Sickle Cell Disease ........... Il

Genetic Counseling and Fatal and Chronic

Disease .............. 18

On Sickle Cell Anemia and Race....... 23

III. METHODOLOGY . . . . . . . . . . . 27

Description of Samples . . . . . . . 27

Description of Research Procedures . . . . 30

Method of Statistical Analysis . . . . . 34 
IV: FINDINGS AND RESULTS . . . . . . . . . . . . 35

Introduction . . . . . . . . . . . . 35

Families Experlencing Sickle Cell Anemia . . . 35

Questionnaire Form A . . . . . . . . 35

General Knowledge and Awareness of Sickle

Cell Disease . . . . . . . . . . 54

Questionnaire Form B . . . . . . . . 54

V. DISCUSSION OF RESULTS . . . . • . . . . . . 71

Questionnaire Form A. . . . . . . . 71

Questionnaire Form B . . . . . . . 73

Limitations . . . . . . . . . . 74

Conclusions and Recommendations . . . . 75

Implications for Further Research . . . . 76

BIBLIOGRAPHY • • • • . . • • • • • . . . . . 77 APPENDICES . . . . . . . . . . . . . . . . . 84

A . INTRODUCTORY LETTER . . . . . . . . . . . . 85

B. QUESTIONNAIRE FORM A . • . . . . . . . . . 87

C. QUESTIONNAIRE FORM B . . . . . . . . . . . . 94 


\section{LIST OF TABLES}

TABLE

PAGE

I. INCIDENCE OF SICKLE CELL DISEASE . . . . . . 28

II. AGE AND SEX DISTRIBUTION OF SICKLE CELL

PATIENTS • • • • • • • • • • • • • • 36

III. ADDITIONAL FAMILY MEMBERS DIAGNOSED WITH

SICKLE CELL DISEASE - • • • • • • • • 36

IV. EDUCATIONAL STATUS OF PATIENTS • • • • • . . 37

V. LIVING ARRANGEMENTS OF PATIENTS • • • • • • . 39

VI. DISTRIBUTION BY PARENTS' AGE . . . • . . . . 39

VII. DISTRIBUTION BY PARENTS' EDUCATION . . . . . . 40

VIII. INCOME DISTRIBUTION . . . . . . . . . 40

IX. SYMPTOMATOLOGY MANIFESTED BY PATIENTS • • • . $41^{\prime}$

X. PASSAGE OF TIME BETWEEN SYMPTOMATIC DISEASE,

DIAGNOSIS WITH SICKLE CELL ANEMIA AND AGE

AT WHICH PATIENT WAS TOLD OF HIS ILLNESS • • 43

XI. DISTRIBUTION ON UNDERSTANDING OF SICKLE

CEIL ANEMIA . . . . . . . . . . . . 46

XII. DISTRIBUTION OF OPINIONS ON RELATED ISSUES • - 48

XIII. DISTRIBUTION BY ETHNIC GROUP AND SEX • • . • • . 54

XIV. FREQUENCY AND DISTRIBUTION BY MARITAL

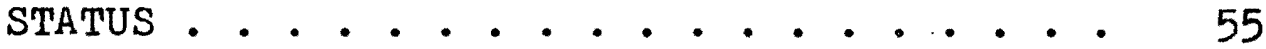

XV. FREQUENCY AND DISTRIBUTION BY EDUCATION • • . 56 
XVI. INCOME DISTRIBUTION . . . . . . . . . 57

XVII. DISTRIBUTION BY RELIGIOUS AFFILIATION . . . 58

XVIII. FREQUENCY AND DISTRIBUTION OF AWARENESS OF

SICKLE CELL DISEASE . . . . . . . 59

XIX. FREQUENCY AND DISTRIBUTION OF EXTENT OF

AWARENESS OF SICKLE CELL DISEASE . . . . 60

XX. FREQUENCY AND DISTRIBUTION OF SOURCE OF

AWARENESS OF SICKLE CELL DISEASE . . . . 62

XXI. FREQUENCY AND DISTRIBUTION OF THE GENERAL

KNOWLEDGE OF SICKLE CELL DISEASE . . . . . 64

XXII. DISTRIBUTION ON OPINIONS ON RELATED

ISSUES . . . . . . . . . . 67 


\section{LIST OF FIGURES}

FIGURE

PAGE

1. Normal Cells - Sickled Cells . . . . . . . . 5

2. Inheritance Patterns of Sickle Cell Disease . . 8

3. Inheritance Patterns of Sickle Cell Disease . . 8

4. Inheritance Patterns of Sickle Cell Disease . . 8 
CHAPTER I

\section{INTRODUCTION}

When a child dies, the enlgma of death strikes heavily at those who experience this tragedy. One of the greatest crises a family must face is the threat of loss through death of one of 1ts members. When it is a child whose death is imminent, the crisis is imbued with an additional dimension of emotion. The loss of this child is especially polgnant when death occurs as the result of genetically acquired traits that lead to a disease for which there is no cure. Sickle cell anemia, because of its genetic origins, and due to the frequent youthfulness of 1ts victims, is such a disease. The following thesis will address itself to this subject of sickle cell anemia--an unfortunate, life destroying human condition.

\section{Areas of Focus}

The flrst area of exploration was undertaken to identify various factors Impinging upon the individual and famlly directly experiencing the disease form of sickle cell anemia. The study included an investigation into the provision or offering of genetic counseling at the time of diagnosis of sickle cell anemia. If genetic counseling had 
been experienced, investigation was made into how much information was retained.

A second area of exploration was undertaken to determine the general awareness of sickle cell anemia among a selected sample population of Portiand, Oregon.

A third area of interest, though not specifically approached as such in data collection, was to explore the possibility that the racial distribution of sickle cell anemia presents unique factors that must be considered by persons involved in services delivery to those families and Individuals affected by sickle cell anemia. More specifically, the authors propose, through review of literature and response to Questionnaire Form $B$, to determine the need for augmentation of traditional counseling methods by an indepth understanding of institutional racism and its effect on the black community as it relates to sickle cell anemia. Some current popular literature and expressed oplnion suggest that the whole subject of sickle cell anemia has become somewhat enmeshed with emotional controversy concerning the concepts of genocide and race. It is the further hope of the authors therefore, to explore and discuss these conslderations of race in an attempt to clarify as thoroughly as possible, their implications in the total context of sickle cell anemia. 


\section{SICKLE CELI ANEMIA}

\section{An Introduction}

For the purpose of the following discussion, and for the remainder of the thesis, the condition of having sickle cell disease will be defined as occurring in one or the other of the two following states: (1) sickle cell anemia-a severe, uncorrectable, and often fatal anemia with many clinical manifestations, and (2) sickle cell trait--a relatively benign condition with symptomatology occurring only under extraordinary clrcumstances.

Hemoglobin functions as the oxygen carrying substance of the blood, and is responsible for the pigmentation of the erythrocytes or red blood cells. The condition of sickle cell anemia results from the presence of an abnormal hemoglobin, known as $\mathrm{Hb}-\mathrm{S}$, in the erythrocytes. The presence of this hemoglobin is hypothesized to have been an asset in protecting 1ts bearer from the effects of malaria in those countries where the occurrence of malaria is common. In 1964, A. C. Allison (Levitan and Montagu 1971), proposed that the heterogygote AS was less susceptible than the normal homozygotes to Falciparum malaria, an often fatal malaria constantly reinfecting its victims with severe and prolonged disease. 
However, for that segment of the population carrying the abnormal hemoglobins, but residing in non-malarial environments, the advantage of hemoglobin $S$ disappears.

In the United States, sickle cell anemia is found predominantly among the black population. According to Wintrobe (1967), the frequency of occurrence of sickle cell trait is 8.5 per cent of the black population. Approximately one out of four hundred blacks (National Sickle Cell Prevention Act, 1971) experiences the anemia 1tself. The incidence of the disease in other races is quite rare, and when it does occur in members of other races, it is usually experienced by persons of Greek, Italian, East Indian, South American and Middle Eastern origins.

\section{Clinical Manifestations}

Sickle cell anemia has been referred to as "the great mimicry" due to the multiphasic manifestations and complexities of its symptoms. Consequently, the risk of incorrect early diagnosis is high. (Lin-Fu 1965)

In infants, symptomatology, particularly in the first few months of life, is bizarre and non-specific. Major complaints usually include colic, fallure to thrive, jaundice, nausea and vomiting, recurrent fever, and swelling in hands and feet. 
In older chlldren, perlodic occurrences of acute ep1sodes with various manifestations, facilitate recognition of slckle cell anemla. These eplsodes, known as "crises" (Lin-Fu, ibld.), are brought about when the erythrocytes or red blood cells begin to slckle. Sickling is the term used to describe the change that occurs within the cells under conditions of reduced oxygenation. The cells elongate and twist into distorted shapes that prohibit free flowing movement of the blood (see Figure 1). It is proposed that "logJams" of these rigid cells form, resulting in impeded circulation in the smaller vessels, thus inhibiting the flow of oxygen to the affected part of the body. This blood flow obstruction causes tissue death, which produces acute, incapacitating pain in any part of the body, fever, and many other non-specific symptoms. This symptom complex comprises the "sickle cell crisis."

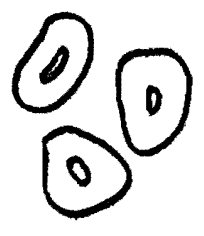

Normal Cells

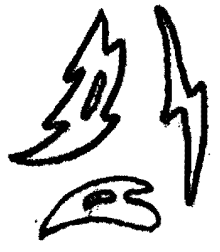

Sickled. Cells 
Other manifestations include necrosis, which might occur resulting in chronic leg ulcers; however, this is less common among those children afflicted with sickle cell anemia than for adults. Inclpient blindness from retinal detachment might also result from sickling and reduced oxygenation in the cells of the eyes. Overall retarded growth and development, and increased susceptiblitty to infections and pneumonia are further manifestations of the anemia. The childhood victim of this 1 llness is usually characterized by a barrel-shaped chest, enlarged protruding abdomen; and thin extremities.

\section{Sickle Cell Trait}

The trait form of sickle cell disease has no clinical manifestations except under extraordinary circumstances, during which the individual might experience a crisis similar to that of the anemia victims. Thus, symptomatology in sickle cell trait can be virtually obliterated by avoiding those circumstances which would precipitate a crisis condition. Sickle cell trait individuals may be incapacitated by (1) conditions of extreme hypoxia, such as flying in an unpressurized aircraft or with underwater swimming, (2) during anesthesia when anoxia has inadvertently occurred, (3) occurrence of occasional severe pneumonia, and (4) extreme physical exercise. 


\section{$\underline{\text { Et lology }}$}

Sickle cell disease, in both its forms, is a genet1cally acquired condition. (Song, ibid) Inherited as an autosomal recessive pattern (Fraser 1966), sickle cell anemia is the homogygous state of the abnormal hemoglobin $S$ gene. The mating of two persons with the sickle cell trait would imply a 25 per cent probability that each offspring w1ll inherit two abnormal genes (Hb-s), a 25 per cent probability that the offspring will inherit two normal genes, and a 50 per cent probability that the offspring will inherit one normal gene and one abnormal gene. In other words, based on statistical calculation using a Mendelian model, (Fraser, ibid, Stern and Sherwood 1966) a family consisting of four offspring will produce one offspring having slckle cell anemia, one offspring that is free of any sickle cell gene, and two offspring having one normal and one abnormal gene (see Figure 2).

The union between one person having sickle cell anemia (the homogygous state of the abnormal hemoglobin $S$ gene) and another person free of a slckle cell gene, will produce offspring having one normal and one abnormal gene (see Figure 3).

Sickle cell tralt is the heterozygous state of the abnormal hemoglobin $S$ gene. The union between a person with 
the sickle cell trait and a person free of the sickle cell gene implies a 50 per cent probability that the of fspring will have the sickle cell trait, and a 50 per cent probability that the offspring will be free of the sickle cell gene (see Figure 4).

INHERITANCE PATTERNS OF

SICKLE CELL DISEASE

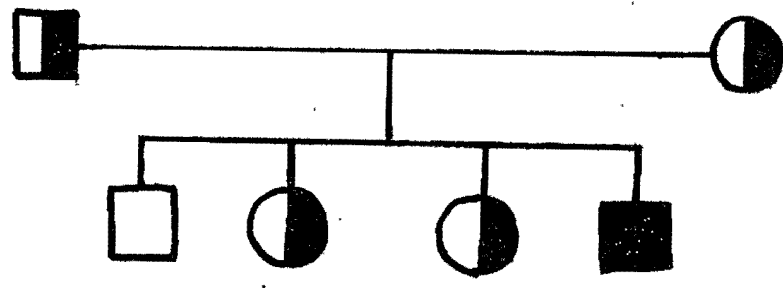

KEY :

Tra1t

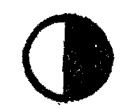

Free

Figure 2 Anemia

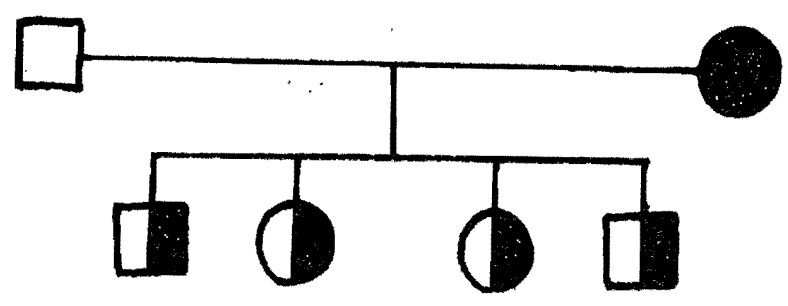

Figure 3

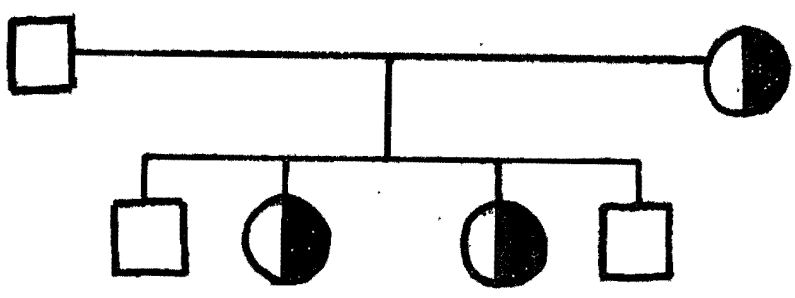

Figure 4 


\section{Treatment}

During crisis situations, treatment is largely supportive and symptomatic. Oxygen administration and the use of analgesics and sedatives seem to be somewhat effective in reducing the painful symptoms of the acute sickling periods.

Management and care must extend beyond medical treatment. Optimal nutrition, satisfactory dental and hygenic care, and avoldance of exposure to infection and crisis precipitating factors are essential in the care of the individual during quiescent periods.

The use of urea has recelved considerable recent interest in the treatment of sickle cell anemia, and feasibility studies are currently underway to determine the extent that urea is effective as a prophylactic measure in the prevention of crisis.. Unfortunately, no treatment has been universally demonstrated or accepted as an effective combatent of sickle cell disease. 
CHAPTER II

REVIEW OF THE LITERATURE

In dealing with a subject area as involved as sickle cell anemia, with its many medical, psychological, and sociological factors, one is faced with the need to selectively discriminate among vast quantities of associated Iiteratures in an attempt to choose a review relevant to the subject area. Since a complete review of all literature was impossible within the scope of this study, the authors established certain criteria for literature selection, and a three-fold direction of inquiry was identified as being most appropriate to the needs of this study.

The first area of concentration dealt with sickle cell anemia and a rather extensive search was done through medical Journals, soclal work Journals, soclology and psychology journals, books dealing with sickle cell anemia and popular lay literature and newspapers.

A second direction of inquiry was made into ilterature involved with genetic counseling and chronic and fatal disease. The authors felt no discussion of sickle cell anemia would be complete without at least a minimal exposure to genetic counseling precepts and practices, and an investigation into research dealing with family loss and adjustment 
to chronic and fatal 1liness. This search was made primar11y into social work and psychology journals.

One final area of inquiry dealt with the subjects of genocide and race. Search into this literature was undertaken with an inference by the authors that the whole issue of sickle cell anemia must be approached with special consideration given to the fact that most victims of sickle cell anemia are black in a soclety long troubled with raclal conflict and strife. Most emphasis in this section was given to popular 11terature on the assumption that this 11terature is most likely read by and an influence on the lay public, and would thus be instrumental in helping to shape public sentiment toward sickle cell anemia.

\section{Sickle Cell Anemia}

One is most impressed in searching the literature for topics dealing with sickle cell anemia, by the dearth of material. Most literature approaching any other than a highly technical, medical model of sickle cell anemia, is practically nonexistent, and for that small amount that does exist, the publish dates are quite recent, usually within the last ten to fifteen years.

Sickle cell anemia was first described by James B. Herrick (1910), when he noticed the sickling phenomenon in the blood of a West Indian student. H1s article, "Peculiar 
Elongated and Sickle-Shaped Red Corpuscles in a Case of Severe Anemia," has subsequently been heralded as the first major work to deal.w1th sickle cell anemia. Huck (1923) suggested that sickle cell anemia was a specific disease entity transmitted according to Mendelian law and affecting primarily individuals of black ancestry. Enmel, in 1917, discussed the origin and mode of formation of sickle-shaped erythrocytes, and appears to have been the first to select and repeatedly use the term "sickle cells." (Song 1971) Hahn and Gillespie (1927) differentiated between the disease and carrier forms of sickle cell disease, and introduced the term "sickle cell trait" to denote the latent or asymptomatic form of the anemia. D1ggs, working with Ahman and Blbb (1933), established the prevalence of sickle cell tralt at 7.3 per cent of the total black population in the United States. This ratio is commonly quoted today, though more recent literature has indlcated a broader range of incidence ranging from 6.4 per cent (Lipton, Rutkow, Margolis 1973) to 14.6 per cent (Boyle, Thompson, Tyroler 1968) of the black population.

In 1949, Iinus Pauling (Song, 1bid.), discovered that sickle cell anemia was a molecular disease, due to a mutation in the DNA molecule. This mutation results in the substitution of a charged for an uncharged amino acid in the Beta chain of the hemoglobin molecule. This leads to an 
abnormal chemical stmucture and a different molecular charge which causes differences in the affinity of the erythrocytes for each other, and is responsible for the disease. (Lehninger 1970) Pauling colned the name "Hb-s" for the abnormal hemoglobin molecule.

Expanding this original theory, Muryama (1966) provided the theoretical basis for future investigations into the utilization of urea as a treatment and crisis preventative, with his hypothesis regarding the molecular mechanisins of slckling.

Much of the current literature concerns itself with investigation and expansion of these early theories of slckle cell anemia, and with the search for more effective preventative measures and hopefully a cure to molecular 11lness. For our uses, however, this I1terature proved to be too highly technical and medically orlented to be useful to this study. Also, since the major thrust of the presentation deals with the broader soclological implications of sickle cell anemia, the review of this section confined itself primarily to that literature addressed to other than a purely medical model.

In searching journals and popular literature, there tended to be conslderable agreement that sickle cell anemia has been a long neglected, major health problem. Scott (1970) suggests: 
Sickle cell anemia is not recognized as an important community health problem or given appropriate consideration in research and health care planning . . probably most neglected major health problem in the nation today.

Senator Robert Kennedy states, ". . no other disease has affected as many people in this country as sickle cell anemia and has been as unattended as this disease." (National Sickle Cell Prevention Act, ibid.)

President Richard Nixon, in his 1971 Health Message stated, "It is a sad and shameful fact that... this disease has been largely neglected throughout our history." (National Sickle Cell Prevention Act, ibid.)

Since public interest has only recently become aroused concerning sickle cell anemia, there is widespread ignorance and lack of understanding, not only among the general. public, but also in the population at risk. (Scott, 1bid.; Binder and Jones 1970; Lane and Scott 1969) The cited 11terature suggests that this lack of understanding, especlally in the risk populations, can have serious implications, and has given rise to considerable controversy concerning the desirability of mass screening to determine if a person has sickle cell anemia or sickle cell trait.

Representative of that point of view supporting the need for mass screening is Scott (1bid.) who states,

With the avallability of a simple test for sickle cell trait carriers which makes mass screening possible, this may be the first hereditary iliness which could be controlled by genetic counseling. 
Harband (1972) supports having state laws requiring blood tests for the sickle cell gene in order to". . give more than lip service to the plight of the Negro with respect to health care."

The desirability of identifying sickle cell trait carriers in order that they may avold situations which would precipitate crisis, is frequently suggested as a justification for mass screening. Mentzer (1970) suggests that death due to sickle cell trait may be more frequent than research indicates, thus making early identification through screening of considerable importance.

In those articles opposing unconditional mass screening, most assumed this stance as an admonition to be aware of the hazards of screening in the absence of extensive and continuous public education. Beutler (1971) suggests that in addition to unnecessary anxiety and psychological harm, that public ignorance might lead to loss of employment, discontinuation of insurance and confusion in differentiating sickle cell anemia and slckle cell trait. Baker (1971) rather succinctly disregards this point of view as so much rhetoric, with her response:

- . that screening programs for sickle cell trait should not be carried out because of anxiety and psychological harm is ridiculous. Why not discontinue chest $X$-Ray surveys for tuberculosis and

Papancolau smears for cancer. 
Whitten (1973) however, stated even more specifically the negative aspects of mass screening. Several of his identified problem areas are listed as follows, all of which seem worthy of note:

1. Identification of prevention as a goal of counseling.

2. Loss of personal rights to choice with mandatory testing.

3. The undue projection of sickle cell trait as a personal health hazard.

4. The establishment of testing programs without a counseling component.

5. The inappropriateness of priorities with testing almed at a target population of young school age children.

6. The false and alarming impressions that are being made through the public medias through such presentations as "Marcus Welby, MD" and Bill Cosby's "To All My Friends on Shore," which create gross misrepresentations of the disease leading to misunderstanding.

7. Sickle cell disease as an excuse for fraudulent fund raising.

8. The creation of divisiveness within the black community over the controversy of the desirablilty of screening.

Thus the controversy continues, and at the time of this writing seemed no closer to any popularly accepted solutions. One pilot screening program described by Nalbandian, Nichols, and Heustis (1971), seemed outstanding for its considerations of the major points of controversy in the 
various attitudes concerning mass screening and their integration into a total program concept. They suggested that comprehensive mass screening can be economically achleved in two phases: by (1) inftially screening through the school system, and (2) testing blood relatives of those students with positive tests. Such an approach eliminates needless screening of large numbers of slckle cell negative Individuals and keeps the costs of the program low.

The ent1re program is predicated on the assumption that voluntary, well-publicized educational programs are essential. They further suggested that the avallability of patient controlled options is necessary for acceptance and success in the program in that persons with positive tests may (1) do nothing, (2) seek the advice of their own physiclan, (3) seek advice of a physician with knowledge of indications and administration of urea therapy, (4) visit a sickle cell clinic and recelve treatment, and/or (5) obtain famlly-wlde genet1c counseling from black geneticlsts.

The screening program also suggested that for maximum effectiveness, the program should be presented by black leaders with much publicity, that the program must be free and voluntary, that special effort must be made to include high school age students and that careful record compilation is essential. 
Genetic Counseling and Fatal

and Chronle Iliness

Genet1c counseling, based on knowledge of human genetics, concerns itself with hereditary disease. One of the major goals of genetic counseling is the prevention of hereditary defects through the use of laws governing inheritance. The geneticist can often accurately predict the probability of occurrence of hereditary disease in the same family .

However, the offering of probability risk is not sufficlent for parents having a child with a birth defect or to potential parents having a known hereditary defect existing within the family. The genetic counseling process must also concern itself with the soclological and psychological impact of the genetic advice to parents or potential parents. It is the role of the genetic counselor to provide parents or potentlal parents seeking genetic prognosis, information on the nature of the hereditary disease and the probabllity of recurrence of the birth defect. The purpose is to allow parents or potential parents to make the decision of whether or not to have children based on the medical knowledge about the disease in question. It is not the role of genetic counseling to declde whether or not a couple should have children.

Limited research has been done exploring the impact of sickle cell anemia on the family or to the occurrence of and 
response to genetic counseling as it relates specifically to sickle cell anemia. However, the authors feel that basic concepts and research dealing with the areas of genetic counseling and chronic and fatal disease might be generallzed to embrace sickle cell anemia. No attempt was made to complete an exhaustive search of literature in these areas, but rather an attempt was made to establish a point of reference and broadened perspective of genetic counseling and 1liness in children in general.

A sampling of literature from these flelds suggests that a family reacts in a fairly predictable manner to the enormity of the stress when they are first informed that theirs is a defective child who may or may not reach adulthood. According to Gordon and Kutner (1965), the inftial responses of parents to learning about their child may include: "(1) shock, (2) anxiety and confusion, (3) denial, (4) rejection of the child, and (5) criticism of the diagnosing physician." Cohen (1972) goes on to state that this is a period of intense grief during which time a family may not "hear" what is being sald to them. This can have crit1cal 1mplications for the family since it is usually at this time that the diagnosis is made and information about the genetic nature of the problem is given. (Schultz 1966) Occasionally the family may even seek the opinton of other 
doctors as a result of their inability to accept the painful diagnosis.

During this period of trauma, Gordon (ibid.) suggests that

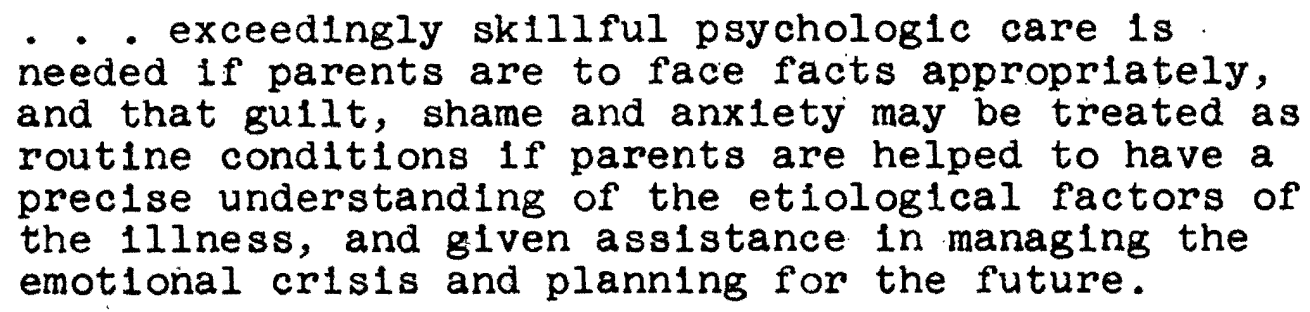

The whole impact of a crisis implied with the diagnosis of fatal illness can overtax the psychological resources of a family. (Parad and Caplan 1960) Any genetic counseling therefore must do more than mere supplement of information, by allowing the working through of intense feelings of powerlessness, anger, guilt, and depression. (Neser and Sudderth 1965) This working through of emotions may express 1tself in various ways, but most commonly through anger (Nolfe 1967), directed for example at phys1clans, at hospitals, or at those involved in any way with the diagnosis of their child.

Schultz suggests that although a complaint might be due to ineptness, usualiy ". . . It is because the news Itself is so painful, that everything and everyone connected with 1t, seems unpleasant to the family." (Schultz, 1bid.) When the family has recovered from the inftial shock perlod, it is likely they will be more able to deal with 
realistic discussion of the disease itself. This period in fact, is likely to be filled with questions concerning the 11 néss with 1ts many sociological and psychological facets. (Gordon and Kutner, 1b1d.) Albin, et al (1971) emphasizes the need at this point, to discuss the disease fully in terms of outcome and treatment while helping the parents to accept the reality that early diagnosis would have no effect on prognosis.

After a family has learned to handle 1ts anger, adjustments can be made in response to the reality of da1ly needs. (Cohen, ibid.)

When a couple is faced with the decision of whether or not to have future children, genetic counseling plays a critical role. Parents who have experienced the tragedy of bearing a defective child inevitably will question why the event happened to them and their responsibility in the genesis of the 1llness. (Schultz 1966; Nolfe 1967) Thus one major responsibility of genetic counseling is to help. the parents understand the origins and cruclal facts of the 1llness; to help the family ". . . secure and comprehend sufficient and acceptable information despite the emotional overlay created by knowledge of the disease." (Gordon and Kutner, 1b1d.)

In addition to this emphasis on education as requisite to any realistic choice about family planning, Iiterature 
supported the precept that genetic counseling leaves the ultimate decision of whether or not to have children to the couple. The agreement was strong in the literature covered for this discussion, that the task of genetic counseling is to help a person ". . Integrate genetic information and make his own decisions for optimum adjustment." (Neser and Sudderth, ibid.)

Although no published material could be located dealing specifically with genetic counseling and sickle cell disease, a workshop held June 28, 1972 in San Francisco, California, moderated by James Tillman, addressed itself exclusively to this subject. The authors felt several points were worthy of note and have consequently included them in this section.

The workshop suggested that goals for genetic counselIng and family planning must be clearly defined in terms of impact not only on the individual, but on black soclety. Emphatic distinction was made that counseling should be informative rather than advisory and therefore would not be the imposition of values by others on an individual, but education. The workshop suggested that counseling should be available on an ongoing basis,

. . designed to suit the varied needs of those with sickle cell trait and those with sickle cell anemia who would need expert professional counseling from early childhood so as to develop in the1r 
children not only an understanding of the disease, but.. . the development of a positive self lmage.

\section{On Sickle Cell Anemia and Race}

Some risk is inherent in a discussion of implications of race relating to a subject as broad and as complicated as sickle cell anemia. One runs the danger of over inference and excessive assumption when literature is conflicting, controversial and frequently statement of subjective opinion rather than legitimate research. However, the authors in this section hoped to get a feel of the literature most likely read by and of influence to the general lay public. With the exception of the Congressional Record (National Sickle Cell Prevention Act, ibid.) most ilterature in this section confined 1tself to popularily read magazines and newspapers. References, opinlons, and general trends of agreement are simply stated as they appeared in the Iiterature, and as they seemed relevant to this presentation. During the 1971 session of Congress, in subcommittee hearings regarding senate B1ll 2676, to provide for the prevention of sickle cell anemia (National Sickle Cell Prevention Act, (bid.), the late Senator Robert Kennedy stated:

PKU--phenylketonuria--occurring about once in 10,000 births and cystic fibrosis occurring once in every 3,000 births, almost exclusively among white people, have attracted astronomical amounts of money in the struggle to end the struggle they cause. But sickle 
cell anemia, which occurs much more frequently, has been neglected and ignored just like most other conditions that affect only black people. As we look at the problem of how to produce rellef for the victims of sickle cell anemia, we must also focus on the fundamental soclal and physical components of this problem with the same intensity that we study the problem's medical research and treatment aspects . . . If cystic fibrosis or muscular dystrophy struck the lives of white families in the proportion that sickle cell anemia affects black Americans, our public commitment to it would be as stubborn as our persistance. . to blow up the tiny island of Amchitika. To avold searching for the clues to that mystery (of sickle cell anemia), as an excuse that this is an unsurmountable task, is merely a cover for racism.

Jacob K. Javits, U.S. Senator from the state of New York goes on to add, "For too many years, sickle cell anemia - . has been 1gnored as one of the greatest killers of our Nation's people."

Edward W. Brooke, U.S. Senator from Massachusetts, states that volunteer work in 1968 raised over seven million dollars for muscular dystrophy, two million dollars for cystic fibrosis, and fifty thousand dollars for sickle cell anemia. Since this time, fifteen million dollars has been federally appropriated to funding research, screening and public education for sickle cell anemia during 1973. This In turn, has given rise to more public outcry. Newsweek (February 12, 1973) has suggested several reasons for this response. According to this source, controversy has resulted from poor education programs that have unduly 
frightened the black community, that some see the entire effort of education and stress on sickle cell anemia as an effort to divert blacks from more pervasive 1ssues of health care and well-being, that mass media has exaggerated the hazards of sickle cell anemia, calling it the "killer disease" and "Black scourge," that const1tutional1ty of mass screening is questionable, that counseling aimed at school children is premature, and that a strong emphasis on family planning in the black community smacks of genocide. The Black Panther (May 27, 1972) is even more critical of the sudden emergence of foundations that "do not have as their goal the wiping out of sickle cell anemia . . but would rather the disease remain, killing off Black people." The Black Panther goes further to describe the recent interest in sickle cell anemia as a "Black gold mine to be opportunistically tapped at the expense of Black people's lives."

Powledge (February 1973) carries this concept a step further by describing sickle cell anemia as a "political disease." She states, "Much of the motivation for sickle cell screening has been unquestionably decent, but it has been obscured by a Republican administration's desire to make inroads on the black vote." She goes on to state that:

Some impassioned critics charge that. . screening laws are an attempt at genocide, . . Judging from a recent study in which more than half the blacks interviewed expressed fear that whites were out to reduce the black population by birth control measures. 
Carl Rowan (The Oregonlan, December 4, 1972), a nationally acclaimed syndicated fournalist, stated, ". . the sickle cell program is on the verge of becoming a new American tragedy," due to the rise in controversy, mismanagement of program and funds, and division created within the black communities.

Most popular literature presents an accurate description of the disease, stressing that it strikes at more than just the black populations and that the disease is not socially contaglous comparable to active tuberculosis or measles, and is therefore not to be publically feared. Literature also supports the need for unity among black people in facing this disease. Dick Campbell, director of the Foundation for Research Education in sickle cell disease, New York City, states, ". . . at least blacks are realizing we have to flght this thing out ourselves." (Ebony, October 1971) 
CHAPTER III

METHODOLOGY

In view of the broad and interrelated areas of research to which the present study was directed, it was necessary to obtain samples of two different population groups. Separate instruments were devised in order to explore the specified areas of research among the selected samples.

\section{Description of Samples}

A letter was sent to all known medical clinics in the Portland Model Clties area who screen for sickle cell disease. The purpose of contact was to obtain a sample for the exploration of factors, resulting from the birth of a child with sickle cell anemia, that might have an effect on the family and individual family members. A total of four clinics recelved a letter of request. A copy of the letter may be found in Appendix A. One of the clinics, People's Free Health Clinic, responded favorably to the request. of the four cases referred by this clinic however, three were identifled as having sickle cell trait, and were therefore inappropriate for the present study. Two of the clinics stated that federal guidelines did not permit cases to be 
used for research purposes, although relevant statistical data on the incidence of sickle cell disease was provided (see Table I). The fourth clinic was unable to provide the authors with cases or relevant statistical data. In addition to the inftial letter contact, personal contact was made with each of the clinics, exclusive of the People's Free Health Clinic.

The sample population consisted of five families. At least one member of each famlly had been diagnosed with sickle cell anemia. Of the five particlpating families, four were referred from the University of Oregon Medical School, Division of Medical Genetics, and one was referred by the People's Free Health Clinic.

TABLE I

INCIDENCE OF SICKLE CELL DISEASE*

\begin{tabular}{cccc}
\hline & $\begin{array}{l}\text { Total number } \\
\text { tested for } \\
\text { sickle cell } \\
\text { disease }\end{array}$ & $\begin{array}{l}\text { Number diag- } \\
\text { nosed with } \\
\text { sickle cell } \\
\text { anemia }\end{array}$ & $\begin{array}{l}\text { Number } \\
\text { tested with } \\
\text { sickle cell } \\
\text { trait }\end{array}$ \\
\hline \#1 & 3423 & 3 & 184 \\
$\# 2$ & 216 & 0 & 60 \\
Total & 3639 & 3 & 244 \\
\hline
\end{tabular}

* Data based on approximately one year period. 
Each family was initially contacted by a staff person from the referring clinic. After the family gave consent for the interview, each of the families was personally contacted and the questionnaire administered.

A quota non probability sample of ninety-nine subjects was used for the investigation of the awareness and general knowledge of sickle cell disease in Portland. Non probability sampling was used to increase the probability of equal or near equal sampling of the black and white populations.

The 1970 census tract for Portland, Oregon was used as a source for locating the potential sample. In order to obtain a representative sampling of the Portland black population for this investigation, census tracts containing four hundred or more blacks were randomly selected. Thus, fifty of the subjects resided in tracts characterized as having four hundred or more blacks and forty-nine of the subjects resided in tracts characterized as having a predominantly white population.

To allow for a systematic sampling plan, every third house located in the selected tracts was chosen to be a respondent to the questionnaire. To increase the probability of a representative sampling within the population groups, the authors administered the data at 1rregular perlods during days, evenings, and weekends. 


\section{Description of Research Procedures}

Due to the paucity of research on the soclological and psychological implications of slckle cell disease, an exploratory descriptive research design was felt to be most appropriate for the present study. Instruments used for data collection took the form of questionnaires, devised by the authors specifically for the study.

One questionnaire, form $A$, was devised for administration to those families directly experiencing sickle cell anemia. The intent was to obtain information about intrafamilial and/or extrafamilial factors that may be identified as having some effect on the individual and the family. The authors also hoped to provide a scheme for identifying the frequency of genetic counseling and the extent of retention of the information acquired in counseling. Because of the nature of the study and the limited number of cases of slckle cell anemla avallable for study, Form A was not amenable to pre test. However, it was the opinion of the authors and the thesis consultants that Questionnalre Form A met the objectives of the study.

The questions presented in Questionnalre Form A were a combination of "fixed-alternative" and "open-ended" type. It was the opinion of the authors that the "open-ended" questions in this questionnalre would allow for greater 
flexibility in relating matters of concern for those families directly experlencing sickle cell anemia. A complete copy of Questionnalre Form $\mid$ A may be found in Appendix B. Questionnaire Form A was divided into five major sections. The first major section designated for identifying data, consisted of six categories. The first category, family composition, was divided into two subcategorles. The first subcategory dealt with the 1dentified patient: age, sex, education, and approximate number of days absent from school during the last academic school year resulting from 1liness assoclated with sickle cell anemia. The second subcategory dealt with the parents of the 1dentifled patient: age, education, employment, and income. The second category was designed to 1dentify the existence of insurance that covered medical expense incurred by sickle cell anemia and changes in insurance rates, or cancellation of any insurance as an outgrowth of the expenses incurred from the identified patient's illness.

Ethnic group and religious affiliation were the third and fourth categories respectively.

The fifth category dealt with the identification of any additional family members having slckle cell disease in the patient's immediate family. 
Living arrangements of the ldentifled patient composed the sixth category. (Parents, foster parents, institution for children, etc.)

The second major section in Questionnalre Form A dealt with the onset of awareness and understanding of sickle cell anemia. Circumstances surrounding diagnosis refer to the extent of awareness of sickle cell anemia, and to the events and symptomatology subsequently leading to the diagnosis of sickle cell anemia. The approximate number of times the identified patient was hospitalized for illness assoclated with sickle cell anemla is also identifled.

Genetic counseling, including identification of members of the identified patient's family who recelved counseling was examined in the third major section: length of time following the diagnosis for sickle cell anemia to the time that counseling occurred, recall of information acquired from counseling, and evaluation of acquired counseling.

The fourth major section dealt with reactions to the events that followed the diagnosis of sickle cell anemia in terms of acceptance of the diagnosis, the awareness and understanding of the illness in the identified patient, and understanding in other family members of the identified patient's 1liness. 
Opinions relating to issues on hereditary disease, illness in children, mass screening for sickle cell disease, family planning, and particularly, issues related to sickle cell disease were requested in the fifth major section.

A second questionnaire, Form $B$, was specifically devised for administration to a selected population sample in Portland, Oregon. The purpose of Questionnalre Form B was to obtain information on the awareness of sickle cell disease among the selected population. The questions presented in this questionnaire were restricted to a "fixedalternative" type.

Questionnaire Form B was divided into three major sections. A complete copy of Questionnalre Form B may be found in Appendix C.

The first major section was designated as identifying data, and consisted of nine categories: sex, age, marital status, education, employment, income, ethnic group, and religious affiliation.

Indicators for the awareness of sickle cell disease were presented in the second major section. Additional information on the extent of awareness and knowledge about sickle cell disease was included in this section.

The third major section consisted of opinions relating to issues of hereditary disease, illness in children, mass 
screening for sickle cell disease, famliy planning, and particularly, issues related to sickle cell disease.

A pre-test on the potentlality of Questionnaire Form $B$ as a research instrument indicated that this questionnaire was feasible for the study.

Method of Statistical Analysis

The data collected on Questionnalre Form A was tabulated for each of the categories. Nonquantifled data was used in reporting the findings and the results of the research in this questionna1re. The authors' purpose in using nonquantified data was to better understand how the birth of a child with sickle cell anemia affected these families and to establish areas for further research.

The data collected on Questionnalre Form B was tabulated and means and standard deviations were computed for each of the categorles in Section I and each of the items in Sections II and III. Means and standard deviations were computed on the black and white subjects in the sample. The purpose was to compare the distribution of response in the black and white samples as well as the overall distribution of response among the total sample in the study. 
CHAPTER IV

FINDINGS AND RESULTS

Introduction

It was the purpose of this investigation to explore factors 1dentified as affecting families directly experiencIng sickle cell anemia, and the awareness of sickle cell disease among a selected population of Portland, Oregon. Chapter IV includes presentation of findings and results.

\section{Families Experiencing Sickle Cell Anemia}

\section{Questionna1re Form A}

A total of seven patients diagnosed with sickle cell anemia was found in the sample of five families. In three of the families in the sample, one famlly was dlagnosed with slckle cell anemla. One of the famliles was found to have one member diagnosed with sickle cell anemia, and a second member deceased as a result of the disease. One of the families contalned three family members diagnosed with sickle cell anemia. Four of the patients in the sample were male and three of the patients in the sample were female. The age of the patients ranged from eleven years to twentytwo years (see Table II). Additional members of the 
patient's immediate family diagnosed with sickle cell disease are identified in Table III, exclusive of the patient's parents.

TABLE II

AGE AND SEX DISTRIBUTION OF

SICKLE CELL PATIENTS

\begin{tabular}{lccc}
\hline Years & Male & Female & Total \\
\hline $10-12$ & 1 & 1 & 2 \\
$13-15$ & 2 & & 2 \\
$16-18$ & & 1 & 1 \\
$19-21$ & & 1 & 1 \\
$22-24$ & 1 & & 1 \\
\hline $\mathbf{N}=7$ & &
\end{tabular}

TABLE III

ADDITIONAL FAMILY MEMBERS DIAGNOSED

WITH SICKLE CELL DISEASE

\begin{tabular}{|c|c|c|c|c|c|}
\hline Case & $\frac{\text { Sib }}{\text { Male }}$ & $\frac{\text { Ings }}{\text { Female }}$ & Age & $\begin{array}{l}\text { No. Diagnosed } \\
\text { W1th S1ckle } \\
\text { Cell Anemia }\end{array}$ & $\begin{array}{l}\text { No. Diagnosed } \\
\text { With Sickle } \\
\text { Cell Trait }\end{array}$ \\
\hline$\# 1$ & & 1 & 21 & 0 & 1 \\
\hline \#2 & 1 & 2 & $12,11,6$ & 0 & 2 \\
\hline \#3 & 1 & 1 & 14,13 & 0 & 0 \\
\hline$\# 4$ & 3 & 2 & $\begin{array}{c}14,12,11, \\
9,7\end{array}$ & 2 & 0 \\
\hline$\# 5$ & 0 & 0 & 0 & 0 & 0 \\
\hline Total & 5 & 6 & & 2 & 3 \\
\hline
\end{tabular}


TABLE IV

EDUCATIONAL STATUS OF PATIENTS

\begin{tabular}{ll}
\hline Grade & Total \\
\hline $1-3$ & 0 \\
$4-6$ & 1 \\
$7-9$ & 3 \\
$10-11$ & 1 \\
Completed 12th Grade & 2 \\
\hline
\end{tabular}

$\mathrm{N}=7$

Education refers to the grade in which the patient is presently enrolled. Of the two patients completing high school, one of the patients completed two years of college and was presently employed.

The number of days the patients were absent from school due to 11 iness associated with sickle cell anemia durIng the last academic school year ranged from approximately ten to twenty-five days. Although the implications of the patients' absenteelsm on school performance is not dealt with in this study, a high rate of absenteelsm often affects school performance (Duckett, C. L., 1971) and may suggest need for the patients to recelve additional educational services such as tutorlal programs to augment class room instruction. 
Insurance. Insurance coverage for all of the patient's medical expenses was found to exist in two of the families. One of the families described insurance that would cover a portion of the medical expense incurred by the patient's illness. Restricted insurance coverage for the patient until the patient reached a specified age was ident1fied in one of the families and only one of the patients was without insurance coverage. Out of the five families in the sample, one of the families indicated an increase in the rate of insurance because of the patient's illness. There was no cancellation of insurance in any of the families as a result of the patient's 1liness. Those families with medIcal Insurance coverage however, explained that the insurance was obtained through employment benefits. Life Insurance for the patients was presented as a problem for these families, in that none of the familles were able to obtain IIfe insurance for the patient with sickle cell anemia.

Living arrangements. Table $\mathrm{V}$ represents the patients' living arrangements. Two of the patients were found to live with both natural parents in the home. Living arrangements for one of the patients was with the mother only in the home. Three of the patients lived with a mother and stepfather in the home and one of the patients lived independently of his 
parents. Age, education, and income of the patients' parents is presented in Tables VI, VII, and VIII.

TABLE V

LIVING ARRANGEMENTS OF PATIENTS

\begin{tabular}{lc}
\hline Category & Total \\
\hline Natural parents in home & 2 \\
Mother only in home & 1 \\
Father only in home & 0 \\
Mother and stepfather in home & 3 \\
Father and stepmother in home & 0 \\
Not 1iving with parents & 1 \\
\hline
\end{tabular}

$N=7$

TABLE VI

DISTRIBUTION BY PARENTS' AGE

\begin{tabular}{cccc}
\hline \hline Age & Mother & Father & Total \\
\hline $30-34$ & 2 & 1 & 3 \\
$35-39$ & 3 & 3 & 6 \\
$40-44$ & 0 & 1 & 1 \\
\hline $\mathrm{N}=10$ & &
\end{tabular}


TABLE VII

DISTRIBUTION BY PARENTS' EDUCATION

\begin{tabular}{|c|c|c|c|}
\hline Grades Completed & Mother & Father & Total \\
\hline $0-5$ & 0 & 0 & 0 \\
\hline $6-9$ & 1 & 1 & 2 \\
\hline $10-11$ & 1 & 1 & 2 \\
\hline 12 & 2 & 0 & 2 \\
\hline $1-3$ years of college & 1 & 1 & 2 \\
\hline 4 or more years of college & 0 & 2 & 2 \\
\hline \multirow{3}{*}{\multicolumn{4}{|c|}{$\begin{array}{c}\text { TABLE VIII } \\
\text { NCOME DISTRIBUTION }\end{array}$}} \\
\hline & & & \\
\hline & & & \\
\hline Income* & & Total & \\
\hline Less than $\$ 200$ & & 0 & \\
\hline$\$ 200$ to $\$ 299$ & & 0 & \\
\hline$\$ 300$ to $\$ 399$ & & 0 & \\
\hline$\$ 400$ to $\$ 499$ & & 2 & \\
\hline$\$ 500$ to $\$ 599$ & & 0 & \\
\hline$\$ 600$ to $\$ 699$ & & 1 & \\
\hline$\$ 700$ to $\$ 799$. & & 0 & \\
\hline$\$ 800$ to $\$ 899$ & & 1 & \\
\hline$\$ 900$ or more & & 1 & \\
\hline
\end{tabular}


Circumstances Surrounding Awareness of Sickle Cell

Anemia. The onset of awareness of sickle cell anemia for the five families directly experiencing the disease ranged from six to thirteen years. Two of the families were aware of sickle cell anemia thirteen years ago; and two of the families indicated eleven years ago as the onset of awareness of sickle cell anemia. One of the families became aware of sickle cell anemia six years ago. Each family first learned about sickle cell anemia when their child was diagnosed with the disease. All of the patients were symptomatic before the initial visit to the doctor or hospital (see Table IX).

TABLE IX

SYMPTOMATOLOGY MANIFESTED BY PATIENTS

\begin{tabular}{lc}
\hline Category & Total \\
\hline Irritability & 1 \\
Vomiting & 0 \\
Fever & 5 \\
Pain in chest, back, stomach, etc. & 2 \\
Patient seemed more tired than & 2 \\
others of his age & 0 \\
Convulsions & 2 \\
Other (swelling, excessive sleep)
\end{tabular}


As may be seen in Table $X$, the patients' age at the time of the inftial visit to the doctor or hospital for symptomatic disease ranged from five months to thirteen years. On the inftial visit to the doctor or hospital, two of the families were given the diagnosis of sickle cell anemia. One of the families was given the diagnosis of "rheumatold arthritis"; and one of the families was told that the patient had "tired blood, jaundice, and just lazy:" One of the familles was not given any information regarding the patient's illness on the inftial visit to the doctor; however, medication was prescribed. Upon further contact between this family and the doctor, the family was told that the patient had "tired blood and needed a better balanced diet."

The number of times the patients were hospltalized for iliness assoclated with sickle cell anemia was found to range from approximately seven to fifty. Hospitalization is difficult in itself, and for those families experiencing sickle cell anemia, hospltalization may be even more traumatic. The patient is subjected to many blood transfusions and intravenous feedings, and separation from family members. The family is subjected to the emotional strain of walting, coupled with the knowledge that sickle cell anemia is a disease for which no cure is yet known. 
TABLE X

PASSAGE OF TIME BETWEEN SYMPTOMATIC DISEASE, DIAGNOSIS

WITH SICKLE CELL ANEMIA, AND AGE AT WHICH

PATIENT WAS TOLD OF HIS ILLNESS

\begin{tabular}{|c|c|c|c|}
\hline CASE NO. & $\begin{array}{l}\text { Age of patient on } \\
\text { initial visit to } \\
\text { doctor or hospltal } \\
\text { for symptomatic } \\
\text { disease }\end{array}$ & $\begin{array}{l}\text { Age of patient at } \\
\text { time of diagnosis } \\
\text { with sickle cell } \\
\text { anemia }\end{array}$ & $\begin{array}{l}\text { Length of time follow- } \\
\text { lng diagnosis with } \\
\text { sickle cell anemia } \\
\text { until patient learned } \\
\text { of lilness }\end{array}$ \\
\hline 1 & 6 months & 6 months & $6-7$ years \\
\hline 2 & 9 years & 9 years & 2 months \\
\hline 3 & $\begin{array}{l}\text { During infancy-- } \\
\text { age not speci- } \\
\text { fled. }\end{array}$ & 17 years & 17 years \\
\hline 4 & 5 months & 13 months & 6 years \\
\hline 5 & 1 year & 1 year & $\begin{array}{l}\text { Age not specified-- } \\
\text { when parents felt } \\
\text { patient was old } \\
\text { enough to learn of } \\
\text { lilness. }\end{array}$ \\
\hline
\end{tabular}


An incorrect diagnosis on the initial visit to the doctor or hospital encountered by those families identified as such, may be indicative of the general lack of awareness of sickle cell disease from ten to fifteen years ago both by the medical profession and the public, along with the multiphasic manifestation of slckle cell anemia which may lead to an Incorrect diagnosis (see Review of Literature, Sickle Cel1 Anemia).

Counseling, comprehension, and reaction. of the five families in the sample, four had recelved counseling. Two of the families were counseled immediately following the patient's diagnosis with sickle cell anemia, and one of the families was counseled less than one month following the patient's diagnosis. In one family, counseling followed the diagnosis for sickle cell anemia by two years. Only one of the families indlcated a complete lack of counseling. Three of the families evaluated counseling as being helpful, and one of the families did not find counseling helpful. of those families counseled, one recalled the genetic origins of slckle cell anemia, the probability of having a "normal" versus "abnormal" ch11d, the pattern of inheritance for sickle cell anemia, the life expectancy for the patient, and the care of the patient. A second family remembered the IIfe expectancy for the patient and the physical symptoms 
that should be observed by the family as a precautionary measure indicative of an impending sickle cell crisis. One of the families recalled information given in counseling on the general care of the patient at home and at school, and particularly, the care of the patient during a crisis. One of the families did not remember the information obtained in counseling.

Reactions to slckle cell anemia. It was found that three of the families sought the opinions of another doctor following the patient's initial diagnosis with sickle cell anemia. Two families accepted the initial diagnosis. One family believed the diagnosis was incorrect. Four of the patients diagnosed with sickle cell anemia had been told of the disease by their parents and one patient learned about the disease through the doctor. However, there were differences concerning the time following the diagnosis that information on the iliness was disclosed to the patient and on what information was revealed regarding the 111 ness. Table $X$ represents the patient's age during the period of diagnosis, and the age of the patient upon learning of his 111ness.

Concerning the nature of the 11lness, two of the patients were told of the need for restricting physical activities, "that because of the 1liness he could not do all 
the things other children were able to do." Two of the patients were told that sickle cell anemia was not to be "feared" and it was not "contagious." One of the patients was notably knowledgeable of the illness as the result of extensive reading and involvement in a local slckle cell project.

Table XI represents both the patient's understanding of his 1llness and that of the other members of the family. One of the families in particular pointed out that initially the patient's and famliy's understanding of slckle cell anemia was poor.

TABLE XI

DISTRIBUTION ON UNDERSTANDING OF SICKLE CELL ANEMIA

\begin{tabular}{lccccc}
\hline \hline Category & Good & Fair & Poor & $\begin{array}{l}\text { Do not } \\
\text { Understard }\end{array}$ & $\begin{array}{c}\text { Have not } \\
\text { Discussed }\end{array}$ \\
\hline Patient & 4 & 1 & 0 & 0 & 0 \\
Parents & 4 & 1 & 0 & 0 & 0 \\
Siblings & 3 & 2 & 0 & 0 & 0 \\
Grandparents & 3 & 1 & 0 & 0 & 0 \\
Other members & 1 & 2 & 0 & 0 & 0 \\
\hline
\end{tabular}

Opinions on related issues. Table XII represents the distribution on opinions relating to issues on hereditary disease, illness in children, mass screening for sickle cell 
anemla, and issues on sickle cell anemla. The parent of one of the patients commented regarding question \#4, "They should be prepared to meet disappointments through parental guldance and not be overly protected." Regarding question \#16, it was commented, "Many, many frustrations (bills, severe 111 ness), threatens the family relationships." 
TABLE XII

DISTRIBUTION OF OPINIONS ON RELATED ISSUES

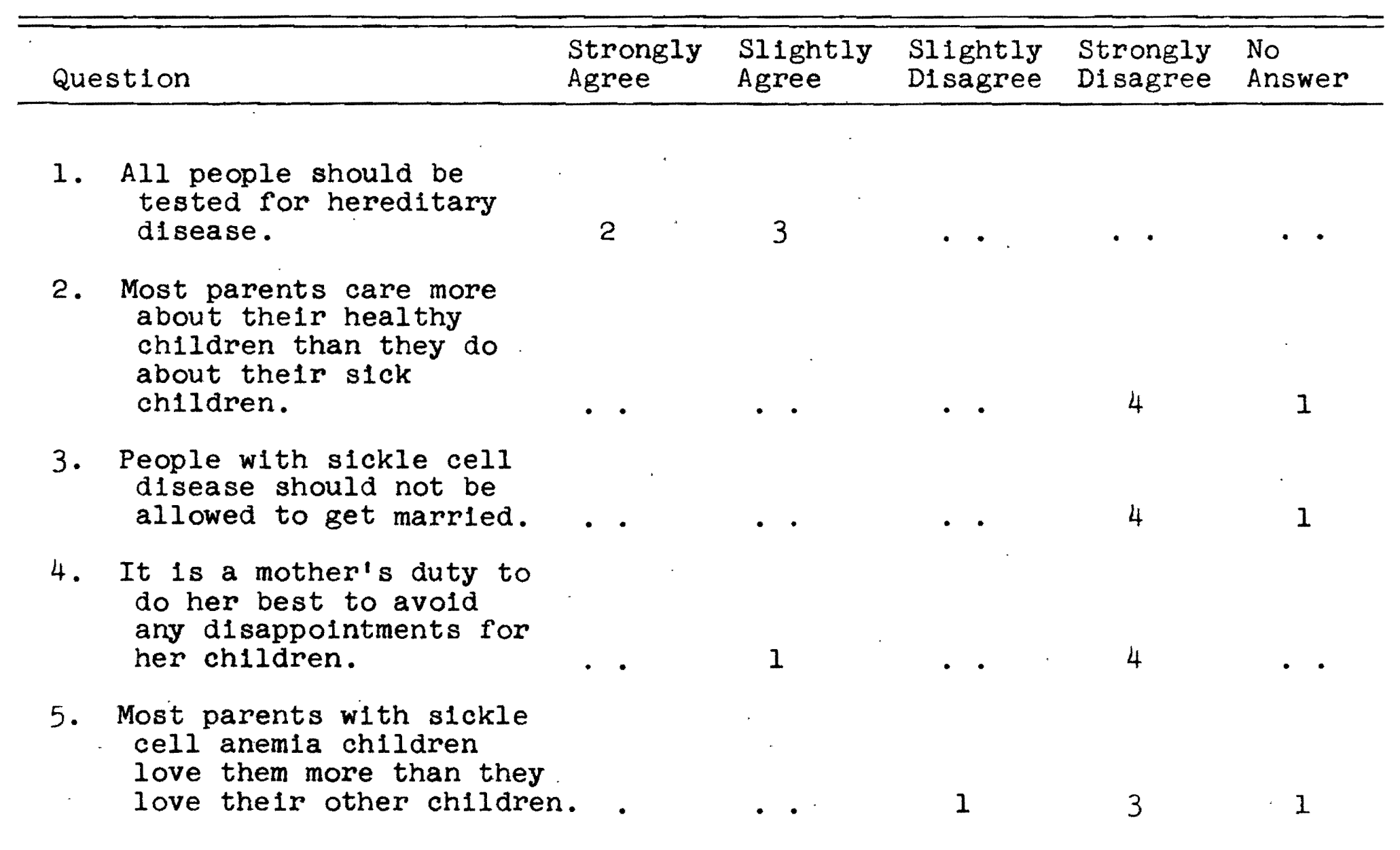


TABLE XII--Continued

\begin{tabular}{|c|c|c|c|c|c|c|}
\hline Que & stion & $\begin{array}{l}\text { Strongly } \\
\text { Agree }\end{array}$ & $\begin{array}{l}\text { Slightly } \\
\text { Agree }\end{array}$ & $\begin{array}{l}\text { Slightly } \\
\text { Disagree }\end{array}$ & $\begin{array}{l}\text { Strongly } \\
\text { Disagree }\end{array}$ & $\begin{array}{l}\text { No } \\
\text { Answer }\end{array}$ \\
\hline 6 & $\begin{array}{l}\text { If a family member has } \\
\text { sickle cell anemia or } \\
\text { the sickle cell trait, } \\
\text { it should be kept a } \\
\text { secret. }\end{array}$ & $\cdot \cdot$ & $\cdot \cdot$ & - • & 4 & 1 \\
\hline $7 \cdot$ & $\begin{array}{l}\text { Sometimes I feel that } \\
\text { the slckle cell anemia } \\
\text { subject is just one more } \\
\text { example of white suprem- } \\
\text { acy and the black man's } \\
\text { burden. }\end{array}$ & • • & - $\cdot$ & - $\cdot$ & 5 & \\
\hline 8. & $\begin{array}{l}\text { Children with sickle cell } \\
\text { anemia or slckle cell } \\
\text { trait should not be } \\
\text { allowed to play with } \\
\text { those chlldren who do not } \\
\text { have sickle cell anemia } \\
\text { or sickle cell trait. }\end{array}$ & . & - $\cdot$ & . $\cdot$ & 4 & 1 \\
\hline 9. & $\begin{array}{l}\text { The future is gloomy for } \\
\text { the family with a member } \\
\text { having sickle cell } \\
\text { anemia. }\end{array}$ & . . & 1 & . . & 4 & . . \\
\hline
\end{tabular}


TABLE XII--Continued

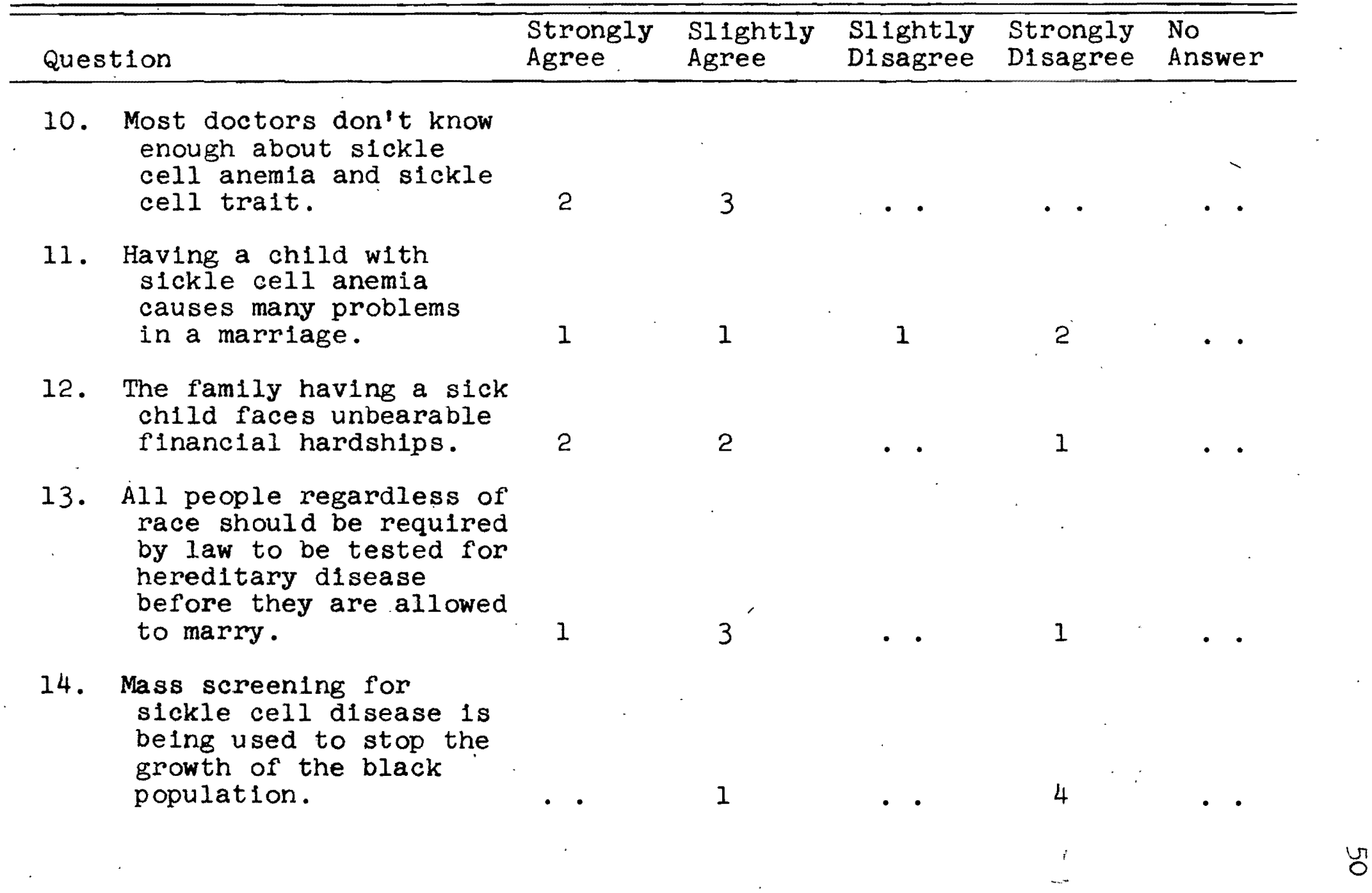


TABLE XII--Continued

\begin{tabular}{|c|c|c|c|c|c|c|}
\hline \multicolumn{2}{|c|}{ Question } & \multirow{2}{*}{$\begin{array}{l}\text { Strongly } \\
\text { Agree }\end{array}$} & \multirow{2}{*}{$\begin{array}{l}\text { Sllghtly } \\
\text { Agree } \\
\\
1\end{array}$} & \multirow{2}{*}{$\begin{array}{c}\text { Slightly } \\
\text { Disagree } \\
\end{array}$} & \multirow{2}{*}{$\begin{array}{c}\text { Strongly } \\
\text { Disagree } \\
4\end{array}$} & \multirow{2}{*}{$\begin{array}{l}\text { No } \\
\text { Answer } \\
\\
\text {. . }\end{array}$} \\
\hline 15. & $\begin{array}{l}\text { People with sickle cell } \\
\text { anemla should be } \\
\text { sterilized. }\end{array}$ & & & & & \\
\hline 16. & $\begin{array}{l}\text { A family is drawn } \\
\text { closer together if } \\
\text { someone in the family } \\
\text { has sickle cell } \\
\text { anemia. }\end{array}$ & . . & 1 & 1 & 1 & 2 \\
\hline 17. & $\begin{array}{l}\text { Healthy brothers and } \\
\text { sisters are cheated if } \\
\text { a family member has } \\
\text { sickle cell anemla. }\end{array}$ & - . & 1 & - . & 3 & 1 \\
\hline 18. & $\begin{array}{l}\text { Black people have no } \\
\text { cholce in their life. }\end{array}$ & 1 & . . & . . & 4 & $\cdot$ \\
\hline 19. & $\begin{array}{l}\text { The name sickle cell } \\
\text { anemla should be } \\
\text { changed. }\end{array}$ & . & - • & $\therefore$ & 3 & 2 \\
\hline 20. & $\begin{array}{l}\text { Sickle cell anemia } \\
\text { means someone with bad } \\
\text { blood. }\end{array}$ & . . & $\therefore$ & . . & 3 & 2 \\
\hline
\end{tabular}


TABLE XII--Continued

\begin{tabular}{llll}
\hline Question & Strongly & Slightly \\
Agree & Agree & Dightly Strongly No \\
Alsagree Disagree Answer
\end{tabular}

21. If sickle cell anemia was found predominantly among the white population, more research would have been done. 
TABLE XII

\begin{tabular}{|c|c|c|c|c|c|c|}
\hline \multicolumn{2}{|c|}{ Question } & $\begin{array}{l}\text { Strongly } \\
\text { Agree }\end{array}$ & $\begin{array}{l}\text { SIightly } \\
\text { Agree }\end{array}$ & $\begin{array}{l}\text { Slightly } \\
\text { Disagree }\end{array}$ & $\begin{array}{l}\text { Strongly } \\
\text { Disagree }\end{array}$ & $\begin{array}{l}\text { No } \\
\text { Answer }\end{array}$ \\
\hline 26. & $\begin{array}{l}\text { Parents should give more } \\
\text { attention to their sick } \\
\text { children because they } \\
\text { have fewer opportuni- } \\
\text { ties to participate in } \\
\text { normal childhood activ- } \\
\text { ities. }\end{array}$ & - . & 3 & - . & 1 & 1 \\
\hline 27. & $\begin{array}{l}\text { People having sickle cell } \\
\text { trait should be pre- } \\
\text { vented from having } \\
\text { children. }\end{array}$ & . & 1 & . $\cdot$ & 2 & . \\
\hline 28 & $\begin{array}{l}\text { Sickle cell anemia and } \\
\text { sickle cell trait is } \\
\text { being used by politi- } \\
\text { clans to get votes. }\end{array}$ & 1 & - . & 1 & 1 & 2 \\
\hline
\end{tabular}


General Knowledge and Awareness of Sickle Cell Disease

Questionnaire Form B

A total population of ninety-nine subjects participated in the sample designed to explore awareness and general knowledge of sickle cell disease. Forty-five of the subjects in the sample were black and forty-seven of the subjects in the sample were white. Seven of the subjects in the sample represented other minority groups: Hawalian, African, and Polynesian. Of the forty-five black subjects in the sample, ten were male and thirty-four were female. of the forty-seven white subjects in the sample, fourteen were male and thirty-two were female (see Table XIII).

Tables XIV, XV, XVI, and XVII represent the maritaI status, educational status, income, and religious affiliation of the subjects in the sample.

TABLE XIII

DISTRIBUTION BY ETHNIC GROUP AND SEX

\begin{tabular}{lcccccc}
\hline Ethnic Group & Male & $\begin{array}{c}\text { Per } \\
\text { Cent }\end{array}$ & $\begin{array}{l}\text { No } \\
\text { Answer }\end{array}$ & Female & $\begin{array}{l}\text { Per } \\
\text { Cent }\end{array}$ & $\begin{array}{l}\text { No } \\
\text { Answer }\end{array}$ \\
\hline Black & 10 & 22 & 0 & 34 & 75 & 1 \\
White & 14 & 29 & 0 & 32 & 68 & 1 \\
Other & 4 & 4 & 0 & 3 & 3 & 0 \\
Total & 28 & & 0 & 69 & & 2 \\
\hline $\mathrm{N}=99$ & & & & &
\end{tabular}


TABLE XIV

FREQUENCY AND DISTRIBUTION

BY MARITAL STATUS

\begin{tabular}{lcccccc}
\hline $\begin{array}{l}\text { Ethnic } \\
\text { Group }\end{array}$ & Single & $\begin{array}{l}\text { Mar- } \\
\text { ried }\end{array}$ & $\begin{array}{l}\text { Di- } \\
\text { vorced }\end{array}$ & $\begin{array}{l}\text { Sepa- } \\
\text { rated }\end{array}$ & Widowed & $\begin{array}{l}\text { No } \\
\text { Answer }\end{array}$ \\
\hline Black & 20 & 16 & 5 & 1 & 3 & 0 \\
White & 16 & 25 & 5 & 0 & 1 & 0 \\
Other & 4 & 2 & 0 & 0 & 1 & 0 \\
Total & 40 & 43 & 10 & 1 & 5 & 0 \\
\hline
\end{tabular}

$N=99$ 
TABLE XV

FREQUENCY AND DISTRIBUTION BY EDUCATION

\begin{tabular}{|c|c|c|c|c|c|c|c|}
\hline $\begin{array}{l}\text { Ethnic } \\
\text { Group }\end{array}$ & $\begin{array}{l}0-5 \\
\text { years } \\
\text { of } \\
\text { school }\end{array}$ & $\begin{array}{l}6-9 \\
\text { years } \\
\text { of } \\
\text { school }\end{array}$ & $\begin{array}{l}\text { 10-11 } \\
\text { years } \\
\text { of } \\
\text { school }\end{array}$ & $\begin{array}{l}12 \\
\text { years } \\
\text { of } \\
\text { school }\end{array}$ & $\begin{array}{l}1-3 \\
\text { years } \\
\text { of } \\
\text { college }\end{array}$ & $\begin{array}{l}\text { College } \\
\text { grad- } \\
\text { uate }\end{array}$ & $\begin{array}{l}\text { No } \\
\text { answer }\end{array}$ \\
\hline Black & 1 & 1 & 5 & 13 & 19 & 5 & 1 \\
\hline White & 0 & 2 & 2 & 9 & 16 & 18 & 0 \\
\hline Other & 1 & . . & . . & 1 & 4 & 1 & 0 \\
\hline Total & 2 & 3 & 7 & 23 & 39 & 24 & 1 \\
\hline
\end{tabular}

$N=99$ 
TABLE XVI

INCOME DISTRIBUTION*

\begin{tabular}{lccc}
\hline Income & Black & White & Other \\
\hline Less than $\$ 200$ & 10 & 8 & 3 \\
$\$ 200-\$ 299$ & 3 & 6 & 0 \\
$\$ 300-\$ 399$ & 3 & 5 & 0 \\
$\$ 400-\$ 499$ & 2 & 7 & 0 \\
$\$ 500-\$ 599$ & 5 & 2 & 1 \\
$\$ 600-\$ 699$ & 2 & 4 & 0 \\
$\$ 700-\$ 799$ & 0 & 2 & 0 \\
$\$ 800-\$ 899$ & 2 & 2 & 0 \\
$\$ 900$ or more & 4 & 8 & 1 \\
No answer & 14 & 3 & 2 \\
Total & 45 & 47 & 7 \\
\hline
\end{tabular}

$N=99$

* Monthly income before taxes. 
TABLE XVII

DISTRIBUTION BY RELIGIOUS AFFILIATION

\begin{tabular}{lccccc}
\hline $\begin{array}{l}\text { Ethnic } \\
\text { Group }\end{array}$ & Protestant & Catholic & Jewish & Other & No answer \\
\hline Black & 31 & 3 & 0 & 2 & 9 \\
White & 20 & 8 & 1 & 8 & 10 \\
Other & 2 & 0 & 0 & 3 & 2 \\
Total & 53 & 11 & 1 & 13 & 21 \\
\hline
\end{tabular}

$N=99$

Awareness of sickle cell disease. The awareness of sickle cell anemla was found to be evenly distributed among the black and white respondents. Numerically, forty-three of the black subjects and forty-three of the white subjects were aware of sickle cell anemia. Forty of the subjects who were black indicated hearing of sickle cell trait as opposed to thirty-four of the subjects who were white (see Table XVIII). 
TABLE XVIII

FREQUENCY AND DISTRIBUTION OF AWARENESS

OF SICKLE CELL DISEASE

\begin{tabular}{|c|c|c|c|c|c|c|}
\hline \multirow{2}{*}{$\begin{array}{l}\text { Ethnic } \\
\text { Group }\end{array}$} & \multicolumn{3}{|c|}{ Sickle Cell Anemla } & \multicolumn{3}{|c|}{ Sickle Cell Trait } \\
\hline & Yes & No & No answer & Yes & No & No answer \\
\hline Black & 43 & 2 & 0 & 40 & 4 & 1 \\
\hline Wh1te & 43 & 3 & 1 & 34 & 10 & 3 \\
\hline Other & 5 & 2 & 0 & 1 & 4 & 2 \\
\hline Total & 91 & 7 & 1 & 75 & 18 & 6 \\
\hline
\end{tabular}

The onset of awareness of sickle cell disease among the subjects in the sample is presented in Table XIX. 
TABLE XIX

FREQUENCY AND DISTRIBUTION OF EXTENT OF AWARENESS OF SICKLE CELL DISEASE

\begin{tabular}{|c|c|c|c|c|c|c|c|c|}
\hline $\begin{array}{l}\text { Ethnic } \\
\text { Group }\end{array}$ & $\begin{array}{l}\text { Less than } \\
6 \text { months } \\
\text { ago }\end{array}$ & $\begin{array}{l}7 \text { months } \\
\text { to } 1 \text { year }\end{array}$ & $\begin{array}{l}2-3 \\
\text { years }\end{array}$ & $\begin{array}{l}4-5 \\
\text { years }\end{array}$ & $\begin{array}{l}6-7 \\
\text { years }\end{array}$ & $\begin{array}{l}8-9 \\
\text { years }\end{array}$ & $\begin{array}{l}\text { Over } 10 \\
\text { years }\end{array}$ & $\begin{array}{l}\text { No } \\
\text { answer }\end{array}$ \\
\hline Black & 1 & 14 & 12 & 2 & 1 & 2 & 8 & 5 \\
\hline White & 1 & 19 & 17 & 2 & 0 & 1 & 3 & 4 \\
\hline Other & 1 & 0 & 0 & 2 & 0 & 0 & 1 & 3 \\
\hline Total & 3 & 33 & 29 & 6 & 1 & 3 & 12 & 12 \\
\hline
\end{tabular}

$N=99$ 
Several sources were generally indicated by the subjects in relating the original source of awareness of sickle cell disease. It was found that a large number of the subjects in both the black and white samples learned of sickle cell disease on television. The majority of these individuals commented that the sickle cell anemia presentation on a Marcus Welby television show was their first introduction to the disease (see Table $\mathrm{XX}$ ). Discussion regarding the authentication of sickle cell anemia as presented through the public entertalnment media is found in the Review of the Literature (Whitten 1973), on page 16. 
TABLE $X X$

FREQUENCY AND DISTRIBUTION OF SOURCES OF

AWARENESS OF SICKLE CELL DISEASE

\begin{tabular}{|c|c|c|c|c|c|c|c|c|}
\hline $\begin{array}{l}\text { Ethnic } \\
\text { Group }\end{array}$ & Doctor & Radio & Friend & $\begin{array}{l}\text { Tele- } \\
\text { vision }\end{array}$ & $\begin{array}{l}\text { News- } \\
\text { paper }\end{array}$ & $\begin{array}{l}\text { School } \\
\text { Clinic }\end{array}$ & Agency & other \\
\hline Black & 10 & 9 & 14 & 14 & 11 & 6 & 6 & 6 \\
\hline White & 4 & 4 & 2 & 27 & 15 & 0 & 5 & 10 \\
\hline Other & 0 & 3 & 0 & 2 & 1 & 0 & 0 & 1 \\
\hline Total & 14 & 16 & 16 & 43 & 27 & 6 & 11 & 17 \\
\hline
\end{tabular}


General knowledge of slckle cell disease. Table XXI shows the distribution of the general knowledge of sickle cell disease. Although most respondents had become aware of slckle cell disease only recently, there was an overall general knowledge and understanding of the disease. Not all of the subjects in the sample were able to clearly differentlate between slckle cell anemia and sickle cell trait. 
TABLE XXI

FREQUENCY AND DISTRIBUTION OF THE GENERAL KNOWLEDGE OF SICKLE CELL DISEASE

\begin{tabular}{|c|c|c|c|c|c|}
\hline Description & Black & White & other & No & answer \\
\hline $\begin{array}{l}\text { Most people who have } \\
\text { sickle cell anemia are } \\
\text { under } 20 \text { years of age. }\end{array}$ & 22 & 19 & 3 & & 55 \\
\hline $\begin{array}{l}\text { Sickle cell anemia is a } \\
\text { disease of the blood. }\end{array}$ & 39 & 36 & 6 & & 18 \\
\hline $\begin{array}{l}\text { People do not get sick } \\
\text { when they have the sickle } \\
\text { cell trait. }\end{array}$ & 15 & 7 & 2 & & 75 \\
\hline $\begin{array}{l}\text { Sickle anemia is a disease } \\
\text { of the aged. }\end{array}$ & 1 & 1 & 0 & & 97 \\
\hline $\begin{array}{l}\text { Both sickle cell anemia and } \\
\text { sickle cell trait are } \\
\text { inherlted. }\end{array}$ & 35 & 32 & 4 & & 28 \\
\hline $\begin{array}{l}\text { Sickle cell anemia is } \\
\text { highly contagious. }\end{array}$ & 3 & 1 & 0 & & 95 \\
\hline $\begin{array}{l}\text { Sickle cell anemia is a } \\
\text { very serious and often } \\
\text { fatal disease. }\end{array}$ & 40 & 35 & 6 & & 18 \\
\hline $\begin{array}{l}\text { A person can have sickle } \\
\text { cell trait and not know } \\
\text { that they have } 1 t .\end{array}$ & 38 & 38 & 4 & & 19 \\
\hline $\begin{array}{l}\text { Sickle cell anemia is } \\
\text { caused by "wild" living. }\end{array}$ & 2 & 0 & 1 & & 96 \\
\hline $\begin{array}{l}\text { Sickle cell anemia is a } \\
\text { disease that usually } \\
\text { strikes black people. }\end{array}$ & 41 & 36 & 6 & & 16 \\
\hline $\begin{array}{l}\text { There is no cure for sickle } \\
\text { cell anemia or sickle cell } \\
\text { trait. }\end{array}$ & 30 & 23 & 3 & & 43 \\
\hline
\end{tabular}


TABLE XXI--Continued

\begin{tabular}{lcccc}
\hline Description & Black & white other No answer \\
\hline $\begin{array}{c}\text { A person can't catch } \\
\text { sickle cell anemia like } \\
\text { mumps or measles. }\end{array}$ & 24 & 22 & 4 & 49 \\
$\begin{array}{l}\text { A person is born with } \\
\text { sickle cell anemia. }\end{array}$ & 35 & 23 & 2 & 39 \\
$\begin{array}{c}\text { A person is born with } \\
\text { sickle cell trait. }\end{array}$ & 36 & 32 & 5 & 26 \\
\hline $\mathbf{N}=99$ & & &
\end{tabular}

Opintions on related issues. Table XXII represents the distribution on opinions relating to issues on hereditary disease, illness in children, mass screening for sickle cell anemia, and issues on sickle cell anemia.

In order to test the means and standard deviations statistical analysis of no difference in the response of the black subjects and the white subjects, a chi square test was computed for two of the opinions. A chi square test on question \#7 yielded no significant difference $\left(x^{2} 5.0097\right)$ on the black and white response. The ch1 square test on question \#14 yielded no significant difference $\left(x^{2} 4.7271\right)$ on the black and white response. On the basis of the results of a means and standard deviations analysis and a chi square analysis, it may be concluded that there are no significant 
differences of opinion concerning identified issues among the black and white respondents in the sample. 
TABLE XXII

OPINIONS ON RELATED ISSUES

Question

\begin{tabular}{llll}
\multicolumn{4}{c}{ Black } \\
\hline 5 & 4 & 3 & 2
\end{tabular}

\#1 A1I people should be tested for hereditary disease.

$\begin{array}{lllll}27 & 9 & 4 & 4 & 1\end{array}$

\#2 Most parents care more about their healthy children than they do about their sick children.

$\begin{array}{lllll}2 & 1 & 11 & 3 & 27\end{array}$

\#3 People with sickle cell disease should not be allowed to get married.

$\begin{array}{lllll}3 & 0 & 12 & 8 & 22\end{array}$

\#4 It is a mother's duty to do her best to avold any disappointments for her children.

$\begin{array}{lllll}8 & 8 & 9 & 11 & 8\end{array}$

\#5 Most parents with sickle cell anemia children love them more than they love their other children.

\#6 If a family member has sickle cell anemia or the sickle cell trait, it should be kept a secret.

$2 \quad 1196 \quad 6.26$

\#7 Sometimes I feel that the sickle cell anemia subject is just one more example of white supremacy and the black man's burden.

\#8 Chilaren with sickle cell anemla or sickle cell trait should not be allowed to play with those children who do not have slckle cell anemia or sickle cell trait. 
TABLE XXII--Continued

\begin{tabular}{llllllllll} 
& & \multicolumn{9}{c}{ White } & & \\
\cline { 3 - 7 } & Means & 5 & 4 & 3 & 2 & 1 & Means & Std. \\
4.266 & 1.095 & 32 & 5 & 6 & 1 & 2 & 4.297 & 1.249
\end{tabular}

$\begin{array}{llllllllll}1.777 & 1.184 & 3 & 3 & 6 & 10 & 25 & 1.914 & 1.230\end{array}$

$\begin{array}{lllllllll}1.977 & 1.177 & 4 & 2 & 18 & 4 & 19 & 2.319 & 1.287\end{array}$

$2.866 \quad 1.439$

$\begin{array}{lllllll}9 & 3 & 10 & 8 & 17 & 2.553 & 1.515\end{array}$

2.133 .1 .217

$2 \quad 2 \quad 20 \quad 4 \quad 19 \quad 2.234 \quad 1.164$

$1.755 \quad 1.151$

$\begin{array}{lllllll}2 & 0 & 13 & 1 & 31 & 1.744 & 1.131\end{array}$

$2.222 \quad 1.396$

$\begin{array}{lllllll}2 & 1 & 13 & 2 & 29 & 1.829 & 1.166\end{array}$

$1.622 \quad 1.113$

$\begin{array}{lllllll}2 & 0 & 10 & 0 & 35 & 1.595 & 1.096\end{array}$ 
TABLE XXII--Cont inued

Question

$\frac{\text { Black }}{5 \cdot 4 \cdot 3}$

\#9 The future is gloomy for the family with a member having sickle cell anemia.

$\begin{array}{lllll}2 & 6 & 10 & 14 & 13\end{array}$

\#10 Most doctors don't know enough about sickle cell anemia and sickle cell trait.

$10 \quad 16 \quad 7 \quad 6 \cdot 6$

\#11 Having a child with sickle cell anemia causes many problems in a marriage.

$\begin{array}{lllll}2 & 11 & 12 & 9 & 11\end{array}$

\#12 The family having a sick child faces unbearable financial hardships.

$9 \quad 16 \quad 5 \quad 11 \cdot 4$

\#13 Al1 people regardless of race should be required by law to be tested for hereditary disease.

$\begin{array}{lllll}10 & 11 & 7 & 7 & 9\end{array}$

\#14 Mass screening for sickle cell disease is being used to stop the growth of the black population.

$\begin{array}{lllll}1 & 2 & 15 & 6 & 19\end{array}$

\#15 People with sickle cell anemia should be sterlilzed

$\begin{array}{lllll}4 & 2 & 12 & 9 & 18\end{array}$

\#16 A family is drawn closer together if someone in the family has sickle cell anemia.

$\begin{array}{lllll}3 & 11 & 12 & 12 & 7\end{array}$

\#17 Healthy brothers and sisters are cheated if a family member has sickle cell anemia.

$\begin{array}{lllll}2 & 1 & 14 & 7 & 20\end{array}$

\#18 Black people have no cholce in their Iife.

$\begin{array}{lllll}4 & 3 & 15 & 4 & 18\end{array}$ 
68

TABLE XXII--Continued

\begin{tabular}{|c|c|c|c|c|c|c|c|c|}
\hline \multirow[b]{2}{*}{ Means } & \multirow[b]{2}{*}{ Std. } & \multicolumn{3}{|c|}{ White } & \multirow[b]{2}{*}{2} & \multirow[b]{2}{*}{$\bar{I}$} & \multirow{2}{*}{ Means } & \multirow[b]{2}{*}{ Std. } \\
\hline & & 5 & 4 & 3 & & & & \\
\hline 2.333 & 1.167 & 6 & 6 & 13 & 7 & 15 & 2.595 & 1.393 \\
\hline 3.400 & 1.338 & 12 & 14 & 10 & 5 & 6 & 3.446 & 1.332 \\
\hline 2.644 & 1.227 & 2 & 16 & 16 & 6 & 7 & 3.000 & 1.122 \\
\hline 3.333 & 1.296 & 12 & 16 & 9 & 6 & 4 & 3.553 & 1.247 \\
\hline 3.066 & 1.528 & 14 & 12 & 9 & 5 & 7 & 3.446 & 1.411 \\
\hline 1.977 & 1.157 & 2 & 1 & 13 & 2 & 29 & 1.829 & 1.166 \\
\hline 2.222 & 1.277 & 4 & 2 & 13 & 2 & 26 & 2.063 & 1.341 \\
\hline 2.800 & 1.179 & 2 & 9 & 24 & 7 & 5 & 2.914 & 0.974 \\
\hline 2.000 & 1.167 & 0 & 5 & 19 & 8 & 15 & 2.297 & 1.040 \\
\hline 2.288 & 1.358 & 3 & 3 & 9 & 5 & 27 & 1.936 & 1.275 \\
\hline
\end{tabular}


TABLE XXII--Continued

\begin{tabular}{|c|c|c|c|c|c|c|c|}
\hline \multirow{2}{*}{\multicolumn{2}{|c|}{ Question }} & \multicolumn{5}{|c|}{ Black } & \\
\hline & & \multirow{2}{*}{5} & \multirow{2}{*}{4} & \multirow[b]{2}{*}{23} & \multirow{2}{*}{$\begin{array}{l}2 \\
4\end{array}$} & \multirow{2}{*}{15} & \\
\hline$\# 19$ & $\begin{array}{l}\text { The name sickle cell anemia } \\
\text { should be changed }\end{array}$ & & & & & & \\
\hline \#20 & $\begin{array}{l}\text { Sickle cell anemia means } \\
\text { someone with bad blood. }\end{array}$ & 4 & 2 & 15 & 4 & 18 & \\
\hline \#21 & $\begin{array}{l}\text { If sickle cell disease was } \\
\text { found predominantly among } \\
\text { the white population, more } \\
\text { research would have been } \\
\text { done. }\end{array}$ & 21 & 10 & 9 & 1 & 3 & \\
\hline \#22 & $\begin{array}{l}\text { Having a child with sickle } \\
\text { cell anemia is a disgrace } \\
\text { to the family. }\end{array}$ & 1 & 0 & 11 & 1 & 31 & \\
\hline \#23 & $\begin{array}{l}\text { Public education about sickle } \\
\text { cell anemla would help } \\
\text { people plan and prepare for } \\
\text { their own families. }\end{array}$ & 21 & 13 & 4 & 5 & 2 & \\
\hline$\# 24$ & $\begin{array}{l}\text { The law should have no } \\
\text { authority over a person's } \\
\text { right to marry or have } \\
\text { children. }\end{array}$ & 18 & 9 & 6 & 5 & 6 & . \\
\hline$\# 25$ & $\begin{array}{l}\text { Screening programs for } \\
\text { sickle cell disease is } \\
\text { necessary for providing } \\
\text { better health care and coun- } \\
\text { seling services. }\end{array}$ & 22 & 8 & 6 & 3 & 5 & \\
\hline$\# 26$ & $\begin{array}{l}\text { Parents should give more } \\
\text { attention to their sick } \\
\text { children because they have } \\
\text { fewer opportunities to } \\
\text { participate in normal child- } \\
\text { hood activities. }\end{array}$ & 7 & 11 & 10 & 12 & 5 & \\
\hline
\end{tabular}


69

TABLE XXII--Cont1nued

\begin{tabular}{|c|c|c|c|c|c|c|c|c|}
\hline \multirow[b]{2}{*}{ Means } & \multirow[b]{2}{*}{ Std. } & \multicolumn{5}{|c|}{ White } & \multirow[b]{2}{*}{ Means } & \multirow[b]{2}{*}{ Std. } \\
\hline & & 5 & 4 & 3 & 2 & $\bar{I}$ & & \\
\hline 2.133 & 1.057 & 1 & 0 & 28 & 7 & 11 & 2.425 & 0.926 \\
\hline 2.200 & 1.375 & 2 & 1 & 19 & 2 & 23 & 2.085 & 1.176 \\
\hline 3.933 & 1.321 & 18 & 8 & 7 & 1 & 13 & 3.361 & 1.660 \\
\hline 1.577 & 1.033 & 3 & 2 & 10 & 1 & 31 & 1.829 & 1.273 \\
\hline 4.022 & 1.196 & 25 & 8 & 8 & 2 & 4 & 4.021 & 1.293 \\
\hline 3.555 & 1.545 & 16 & 5 & 9 & 9 & 8 & 3.255 & 1.524 \\
\hline 3.800 & 1.501 & 27 & 14 & 5 & 1 & 0 & 4.425 & 0.773 \\
\hline 3.066 & 1.268 & 10 & 15 & 7 & 8 & 7 & 3.276 & 1.378 \\
\hline
\end{tabular}


TABLE XXII--Continued

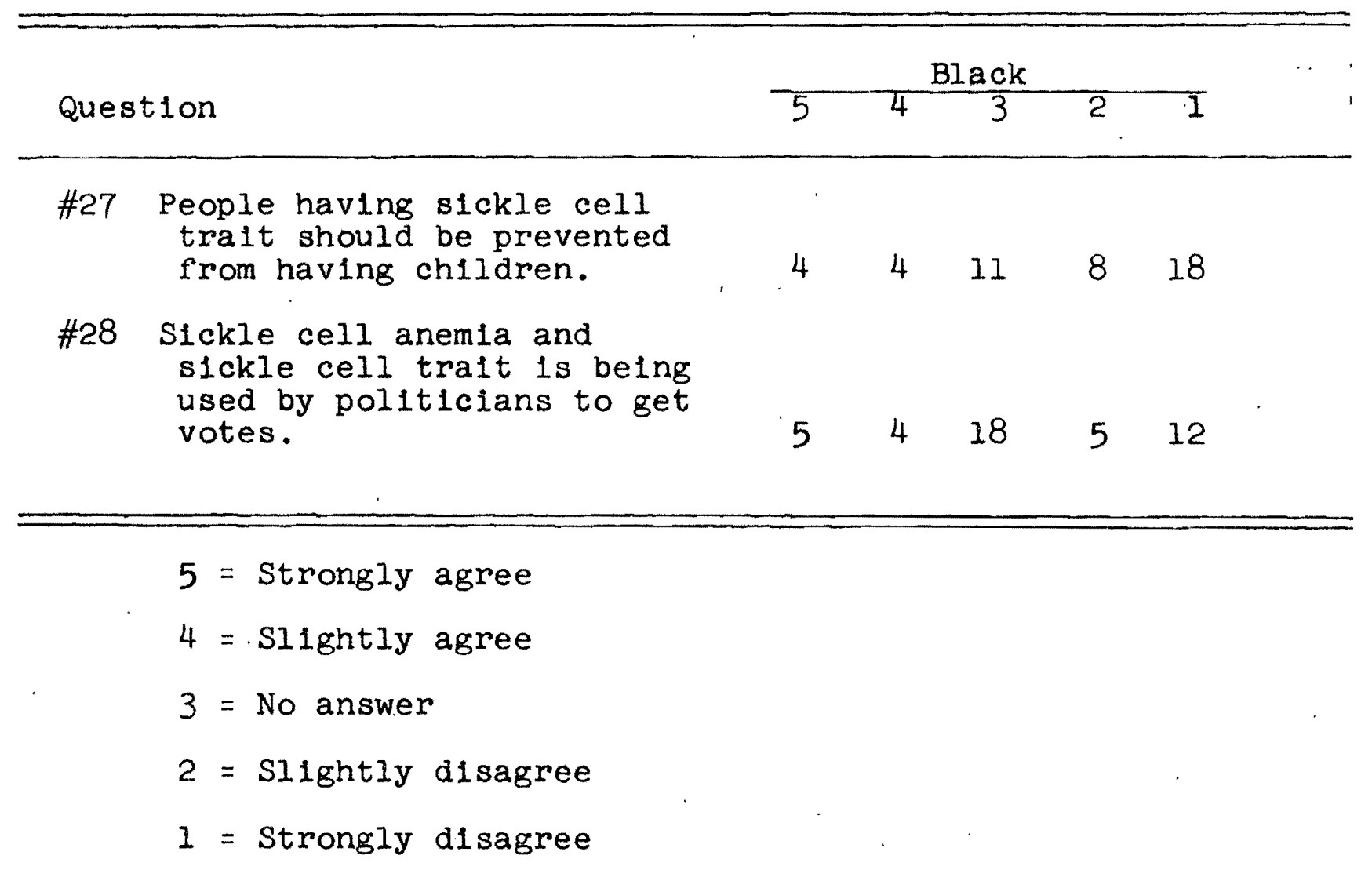


TABLE XXII--Continued

\begin{tabular}{|c|c|c|c|c|c|c|c|c|}
\hline \multirow[b]{2}{*}{ Means } & \multirow[b]{2}{*}{ std. } & \multicolumn{5}{|c|}{ White } & \multirow[b]{2}{*}{ Means } & \multirow[b]{2}{*}{ Std. } \\
\hline & & 5 & 4 & 3 & 2 & $\overline{1}$ & & \\
\hline 2.288 & 1.324 & 3 & 1 & 16 & 7 & 15 & 2.468 & 1.248 \\
\hline 2.600 & 1.338 & 3 & 3 & 25 & 3 & 15 & 2.574 & 1.156 \\
\hline
\end{tabular}


CHAPTER V

DISCUSSION OF RESULTS

Questionnaire Form A

Th1s study was designed to explore the psychosociological responses made by families in adjusting to the painful reality of having a family member with sickle cell anemia. Several general statements may be made about the data collected in Questionnaire Form A.

Even though the study was limited to only five families, there was general agreement among the families that several factors could be identified as having impact on the family. Increased financial burdens due to frequent and extensive hospitalizations and medical care, and infrequent or Inadequate insurance coverage were suggested as factors creating difflculties for the families. The authors suggest therefore, that these two problems would be problematic for any family facing the financial burden of an illness comparable to sickle cell anemia.

In addition, several families indicated that incorrect intilal diagnosis had been made. Constdering the racial overtones of sickle cell anemia, and the controversy of racial stereotyping, one must be aware of the possible psy- 
chological harm done to a child who is diagnosed as "lazy," or to his mother when she is told her child is 111 due to inadequate diet. Incorrect diagnosis of the type mentioned above has implicit negative connotations. The emotional reaction generated may well be complicated at a later point when a correct diagnosis is finally made.

The authors are aware of the "mimic" symptomatology of sickle cell anemia and the consequential possibilities of incorrect diagnosis. However, in response to data collected in this area, incorrect early diagnosis appears to have a traumatic and detrimental effect on the families. It is the opinion of the authors therefore, that the point of diagnosis becomes critical due to the immediate crisis at hand, and must be approached with sensitive, educative genetic counseling and appropriate familial support to help eliminate or reduce the confusion and conflict of early errors in diagnosis, as well as ease somewhat the stress of recelving a terminal diagnosis for a family member.

of the five families questioned, four had experienced genetic counseling. There was no way to determine the extent or focus of counseling, since the only measure used to determine the extent of this counseling was subjective recall of parents. Only one of the families remembered specific factual information in terms of genesis of the disease, probabilities, etc, though it must be considered that these facts 
might not have been discussed with the other families in their counseling sessions. All the families receiving counseling recalled the general care needed in facilitating optimum comfort for the patient, and $11 \mathrm{fe}$ expectancy. It is the inference of these authors, that families can benefit from genetic counseling, but for maximum effectiveness, it must be followed up with further counseling and family support since during the crisis of diagnosis a family may not "hear" or comprehend what is being said to them.

\section{Questionnaire Form B}

In discussing the results of Questionnaire Form $B$, the response is that no statistically significant difference was demonstrated between black and white respondents.

However, the following areas are interesting even though not significant, in that more black than white respondents were aware of sickle cell anemia for a longer perlod of time, and blacks tended to be able to differentiate sickle cell anemia and sickle cell tralt at a higher response rate than whites. More whites than blacks felt sickle cell anemia was an example of the black man's burden, while more blacks than whites felt that greater expenditures In research would have been made if the disease attacked a predominantly white population. Both groups tended to agree 
with the desirability of mass screening as a means of providing better health care.

\section{Limitations of the Study}

In generalizing research findings of the areas of study in this thesis, several limitations must be considered:

1. In the exploration of factors affecting families directly experiencing sickle cell, anemia, only a small number of such families were avallable. for study.

2. Data collection was based on the respondents' recall of information and self reports without further investigation into the accuracy of the reports.

3. The sample used in the investigation into the awareness of sickle cell disease was based on non probability sampling which may create an inherent risk in obtaining a bias sample.

4. The study did not deal with the effects of demographic variables.

5. The instrument of data collection was not designed to discriminately differentiate among choices made in Questionnaire Form B, Section II. 


\section{Conclusions and Recommendations}

In summary, there appeared to be a broad general knowledge of sickle cell disease in the identified target samples, with many interesting comparative responses to the attitudinal survey, but no statisticaliy significant differences in black and white responses.

In response to collected data from the families experlencing sickle cell anemia, and from the search of literature, the following recommendations are made:

1. That all persons experiencing genetic disease have the option to choose genetic counseling and sufficlent community education to know they have this choice.

2. That all genetic counseling include supportive family therapy and education over a sufficient period of time so the family can integrate the information into their own iffe systems.

3. That community educative efforts be infliated to help parents learn and understand more about sickle cell anemia.

4. That any person involved in counseling with sickle cell anemia be acutely aware of the implications of racism and race. 


\section{Implications for Further Research}

As a result of the findings of this thesis, the authors suggest a study into the effect of long-term counseling to determine if it does in fact carry a positive benefit as suggested by the current examination. Also a potentlal area of exploration would be to determine the effectiveness of counseling in general, and genetic counseling in particular. 


\section{BIBLIOGRAPHY}

Albin, A.R., C. M. Binger, and R. C. Stein. "A Conference with a Family of a Leukemic Child," American Journal of Diseased Children, Vol. 122 (October 1971) 362-363.

Baker, Mary. "The Not So Harmless Sickle Trait," New England Journal of Medicine, Vol. 286 (February 17, 1972) 377-378:

Beutler, E., D. R. Boggs, et al. "Hazards of Indiscriminate Screening for Sickling," New England Journal of Medicine, Vol. 285 (December 23, 1971) 1485-1486.

Binder, R. A., and S. R. Jones. "Prevalence and Awareness of Sickle Cell Hemoglobin in a Military Population," Journal of the American Medical Association, Vol. 214 (November 2, 1970) 909-911.

Binger, C. M., A. R. Albin, R. C. Feuerstein, J. H. Kushner, S. Zoger, and Cynthia Mikkelson, "Childhood Leukemia: Emotional Impact on Patient and Family," New England Journal of Medicine, Vol. 280 (February 20, 1969) 414418 .

Bowers, Margaret, Edgar Jackson, James KnIght and Lawrence Le Shan. Counseling the Dying. New York: Thomas Nelson and Sons, 1964.

Boyle, Edwin, Charles Thompson and Herman Tyroler. "Prevalence of the Sickle Cell Trait in Adults of Charleston County, S.C." Archives of Environmental Health, Vol. 17 (December 1965) 891-898.

Bozemap, Mary, Charles Orbach, and Arthur Sutherland. Psychological Impact of Cancer and its Treatment: The Adaptation of Mothers to the Threatened Loss of Their ChIldren Through Leukemia," Cancer, Vol. 8 (JanuaryFebruary 1955) 1-19.

Cobb, Beatrice. "Psychological Impact of Long Illness and Death of a Child on the Family Circle," Journal of Pediatrics, Vol. 49 (December 1956) 746-751. 
Cohen, P. "The Impact of the Handicapped Child on the Family," Soclal Casework, Vol. XIII (March 1972).

"Counterattack on a Killer," Ebony, Vol. 26. (October 1971) 84-86!

Diggs, I. W. "Sickle Cell Crisis," American Journal of Clinical Pathology, Vol. 44 (1965) 1.

- "Genetic Counseling for Sickle Cell Disease Carrlers," New England Journal of Medicine, Vol. 285 (November 1971) 1266-7.

, C. F. Ahman and J. Bibb. "Incidence and Significance of Sickle Cell Trait," Annals of Internal Med1cine, Vol. 7 (1933) 769-773.

Duckett, C. L. "Caring for Chlldren with Sickle Cell Anemia," Children, Vol. 18 (1971) 227.

Evans, Audrey and S. Edin. "If a Child Must Die . . .," New England Journal of Medic1ne, Vol. 278 (January $18,1968) 138-142$.

Fraser, Alex: Heredity, Genes and Chromosomes. New York: McGraw-H111, 1966 .

Fort, A. T., J. C. Morrison, L. W. D1ggs, et al. "CounselIng the Patlent w1th Sickle Cell Disease About Reproduction: Pregnancy Outcome Does Not Justify Maternal Risk," American Journal of Obstetrics and Gynecology, Vol. 11 I (October I, 1971) 324-7.

"Genetic Counseling--Considerations for Talking to Parents and Prospective Parents," Journal of the American Medical Association, Vol. 217 (August 30, 1971) 12151225.

Gordon, Norman and Bernard Kutner. "Long Term and Fatal Illness and the Family, "Journal of Health and Human Behavior, Vol. 6 (Winter 1965) 190-196.

Greenburg, M. S. "Need to Identify Sickle Cell Tra1t," New England Journal of Mediclne, Vol. 282 (March 12, 1970) 629-630.

Hahn, E. V., and E. B. Gillesple. "Sickle Cell Anemla," American Medical Association Archives of Internal Medicine, Vol. 39 (1927) 233-235. 
Hamovitch, Maurice B. "Research Interviewing in Terminal Illness," Soclal Work, Vol. 8 (April 1963) 4-9.

Harband, Newton. "Slckle Cell Tra1t," New England Journal of Medicine, Vol. 286 (February 17, 1972) 377-378.

Herrick, J. B. "Peculiar Elongated and Sickle-Shaped Red Blood Corpuscles in a Case of Severe Anemla," American Medical Association Archives of Internal Medlcine, Vol. 6 (1910) 517-521.

Huck, J. G. "Sickle Cell Anemia," Bulletin of John's Hopkins Hospital, Vol. 34 (1923) 335-339.

Hurt, Peyton. Bibliography and Footnotes. Berkeley: University of California Press, 1968.

Jones, S. R., R. A. Blnder and E. M. Donowho. "Sudden Death in. Sickle-Cell Trait," New England Journal of Medicine, Vol. 282 (February 5, 1970) 323-325.

Kanof, Abram, Bernard Kutner and Norman Gordon. "The Impact of Infantile Amaurotic Familial Idiocy (Tay-Sacks Disease) on the Family," Pediatrics (January 1962) $37-45$.

Lane, John and Robert Scott. "Awareness of Sickle Cell Anemia Among Negroes of Richmond, Va.," Public Health Reports, Vol. 84 (November 1969) 949-952.

Lappe, M., J. M. Gustafson, and R. Rablin. "Ethical and Soclal Issues in Screening for Genetic Diseases," New England Journal of Medicine, Vol. 286 (1972) 1129.

Lehninger, Albert L. Blochemistry. New York: Worth PubIlshing, Inc., $1 \overline{970 .}$

Levitan, Max and Ashley Montagu. Textbook of Human Genetics. New York: Oxford University Press, 1971.

Lindemann, Erick. "Symptomatology and Management of Acute Grief," American Journal of Psychiatry, Vol. 101 (September 1944) 141-148.

Lipton, Jeffrey, Ira Rutkow, and Robert Margolis. "Frequency and Nature of Sickling Disorders," New England Journal of Medicine, Vol. 288 (March 29, 1973) 687688. 
Livingstone, Frank B. Abnormal. Hemoglobins in Human Populations. Chicago: Aldine Publishing Co., 1967.

Lynch, H. T., T. P. Krush, A. J. Krush and R. L. Tips, "Psychodynamics of Early Hereditary Deaths," Diseases of Children, Vol. 108 (December 1964) 605-611.

McCurdy, P.. "Sickle-Cell Tra1t," New England Journal of Medicine, Vol. 282 (May 14, 1970) 1158.

Mendenhall, William. Introduction to Probability and Statistics. California: Wadsworth Publishing Co., Inc., 1967 .

Mentzer, W. C., B. H. Lubin, D. G. Nathan. "Screening for Sickle Cell Trait," New England Journal of Medicine, Vol. 282 (May 14, 1970) 1155-1156.

Michaelson, M. G. "Sickle Cell Anemia: An Interesting Pathology," Ramparts Magazine, Vol. 10 (October 1971) 52-58.

Montagu, Ashley. Man's Most Dangerous Myth: The Fallacy of Race. New York: The World Publishing Co., 1964.

Morlarty, David, M. D. The Loss of Loved Ones. Springfleld, Illinols: Charles C. Thomas, Publisher, 1967.

Morjan, T. J. "S Hemoglobinopathy in a Community Hospital," Journal of the American Medical Association, Vol. 219 (January 1972) 204-205.

Morrissey, James R. "Children's Adaptation to Fatal Illness," Soclal Work, Vol. 8 (October 1963) 81-88.

Mosher, W. B. "Sickle-Cell Trait," New England Journal of Medicine, Vol. 282 (May 14, 1970) 1157-1158.

Motulsky, Arno. "Frequency of Sickling Disorders in U. S. Blacks," New England Journal of Medicine, Vol. 288 (January 4, 1973) 31-33.

, and Frederick Hecht. "Genetic Prognosis and Counseling," American Journal of Obstetrics and Gynecology, Vol. 90 (December 1, 1964) 1227-1241.

Murata, S. "N.w Eddie Smith has a better chance of getting a Rhodes Scholarship: Sickle Cell Anemia," Today's Health, Vol. 49 (December 6, 1971) 54. 
Murstein, B: "The Effect of Long Term Illness of Children and the Emotional Adjustment of Parents," Child Development, Vol. 31 (1960) 157-171.

Nalbandian, R. M., B. M. Nichols, A. E. Heustis, et.al. "An Automated Mass Screening Program for Sickle Cell Disease," Journal of the American Medical Association, Vol. 218 (December 13, 1971) 1680-1682.

Neser, William and Grace Sudduth. "Genetics and Casework," Soclal Casework, Vol. XLVI (January 1965) 22-26.

Nolf1, Mary. "Famllies in Grief: The Question of Casework Intervention," Soclal Work, Vol. 12. (October 1967) 40-46.

Olshansky, Simon. "Chronic Sorrow: A Response to Having a Mentally Defective Child," Social Casework, Vol. XLII (April 1962) 196.

Parad, Howard and Gerald Caplan. "A Framework for Studying Families in Crisis," Soclal Work, Vol. 5 (July 1960) 3-15.

Powledge, T. M. "The New Ghetto Hustle," Saturday Review Sclence, Vol. 1 (February 1973) 38-40.

"Progress in Treating Sickle Cell Anemia," Chemistry, Vol. 44 (Apr11 1971) 21-22.

Racism in America and How to Combat It. The United States Commission on Civil Rights. Washington, D. C.: Clearinghouse Publications, January 1970.

Rosenheim, Sidney. "Sickle Cell Trait and Sudden Death (cont.)" New England Journal of Medicine, Vol. 283 (November 26,1970 ) 1229-1230.

"Row Over Sickle-Cell," Newsweek, Vol. 8 (February 12, 1973) 63-65.

Sch1ld, Sylvia. "The Challenging Opportunity for Social Workers in Genetics," Soclal Work, Vol. 11 (Apr11 1966) $22-28$.

Schultz, Amelia. "The Impact of Genetic Disorders," Social Work, Vol. 11 (Apr11 1966) 29-35. 
Scott, Robert B. "Sickle Cell Anemla--High Prevalence and Low Priority," New England Journal of Medicine, Vol.

- "Health Care and Sickle Cell Anemia," Journal American Medical Association, Vol. 214 (october 26, 1970) $731-734$.

Sellitz, Claire, Marle Jahoda, Morton Deutsch and Stuart W. Cook. Research Methods and Soclal Relations. New York: Holt, Rinehart and Winston, Inc., 1962.

Sherman, I. J. "The Sickling Phenomenon with Special Reference to Differentlation of Sickle Cell Anemia From Sickle Cell Trait," Bulletin John Hopkins Hospital, Vol. 67 (1940) 309.

"The Sickle-Cell Game," The Black Panther, Vol. VIII (May 27, 1972) 10-13.

"Sickle-Cell Trait and Sudden Death," New England Journal of Medicine, Vol. 283 (November 26, 1970) 1229-31.

Song, Joseph, M. D. Pathology of Sickle Cell Disease. Springfield, Illinols: Charles C. Thomas, 1971.

Spencer, S. M. "Sickle-Cell Anemia--A Neglected Killer," Reader's Digest, Vol. 102 (January 1973) 38-40.

Stern, Curt and Eva Sherwood. The Origins of Genetics. San Franc1sco: W. H. Freeman and Co., 1966.

Tips, Robert and Henry Lynch. "The Impact of Genetic Counseling Upon the Family Milieu," Journal American Medical Association, Vol. 184 (Apr11 20, 1963) 183186.

U. S. Congress. Senate. National Sickle Cell Prevention Act. November 11 and 12, 1971. 92nd Congress, First Session. S. Doc. 2676. Washington, D.C.: Government Printing office, 1972 .

U.S. Department of Health, Education and Welfare. Sickle Cell Anemia: A Medical Review, Jane S. Lin-Fu, M.D. 75-5111. Washington, D.C.: Government Printing Office, 1965.

U.S. Department of Health, Education and Welfare. S1ckle Cell Anemia: What It Is, What Can Be Done. Jane S. LIn-Fu, M.D. 1730-0022. Washington, D.C.: Government Printing office, 1972 . 
Vernick, Joel and Karen Myron. "Who's Afraid of Death on a Leukemia Ward?" American Journal of Diseased Children, Vol. 109 (May 1965) 393-397.

Wethers, D. I. "Need to Ident1fy S1ckle-Cell Trait," New England Journal of Medicine, Vol. 282 (March 12, 1970) 630 .

Whitten, Charles. "Sickle-Cell Programming--An Imperiled Promise," New England Journal of Medicine, Vol. 288 (February 6,1973 ) 318-319.

Wintrobe, Maxwell M. Clinical Hematology. Philadelphia: Lea and Febiger, 1942. 
APPENDICES 
APPENDIX A

Portland State UnIversity

School of Social Work

S.W. Ilth and Mill

Portland, Oregon 97201

Dear Jane Doe:

As graduate students at Portland State UnIversity Involved in studying the impact of sickle cell disease on the ind1vidual, family and community to fulfili thesis requirements, we are in the process of exploring the implications and reactions to knowledge of the disease.

As an integral part of this endeavor we feel it essential to explore the reactions to the disease, and the occurrence of counseling with those families who have experience. with the disease in some way. We are specifically interested in those families in which a family member has been diagnosed as having sickle cell anemia or sickle cell trait. Hopefully these families can then be contacted through a questionnaire and personal interview.

We realize the subject of sickle cell disease is highly controversial and sensitive at this time but the research cannot be started without some actual involvement with the families experlencing the disease. It would therefore be most beneficlal if you could help us by supplying a list of these identified families. Any names and information recelved would be treated with complete confidentlality. Results of research will be avallable on request.

The authors' involvement in the study of sickle cell disease evolved in response to experlences with genetic counseling and a sincere concern that this particular disease and its assoclated problems has been serlously neglected in terms of impact on the individual, the family and the community. 
We are available for further information and a personal appointment may be requested if desired at the following numbers: $285-1438$, or $227-4868$, or by malling a card to either of us, C/o Portland State University School of Soclal Work, S.W. Ilth and Mill, Portland, Oregon 97201.

Sincerely,

Marian Gilmore Sharon Goddard

cc: Dr. Robert Blgley

Mr. Jack Finley 


\section{APPENDIX B \\ QUESTIONNAIRE FORM A}

FAMILIES WITH SICKLE CELL ANEMIA

Relation of respondent to patient

Date of Interview

Section I. Identifying Data

Family Composition

Patient

Age of patient

Sex of patient Male (1),

How long has patient Iived in present house?

Less than three years

4 to 5 years

6 to 7 years

8 to 9 years

10 years or 1 onger

No answer

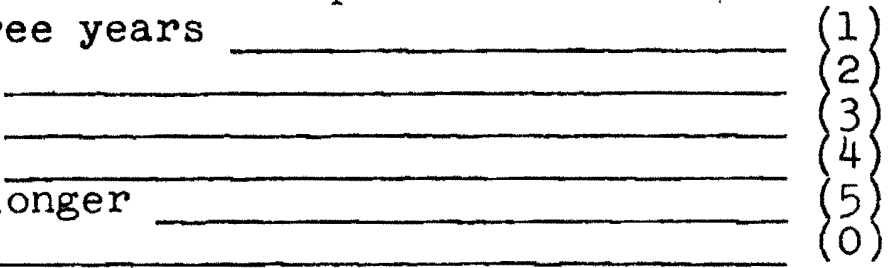

Area of city where house is located.

NW area

$\mathrm{N}$ area

SW area

SE area

$\mathrm{NE}$ area

No answer

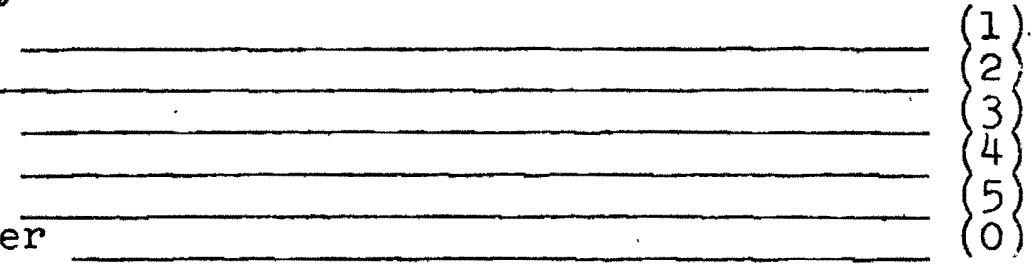

What grade is patient presently in?

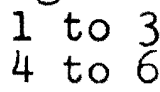

7 to 9

10 to 12

Completed l2th grade

Not applicable

No answer 
Has there been any increase in the rates or cancellation of any insurance because of the patient's iliness? No

To what ethnic group do you belong?

Black
Mexican-American
White
Other Tspecify)
No answer

To what religlous group do you belong?

Protestant
Catholic
Jewish
Other (Specify
No answer

How religious do you consider yourself?

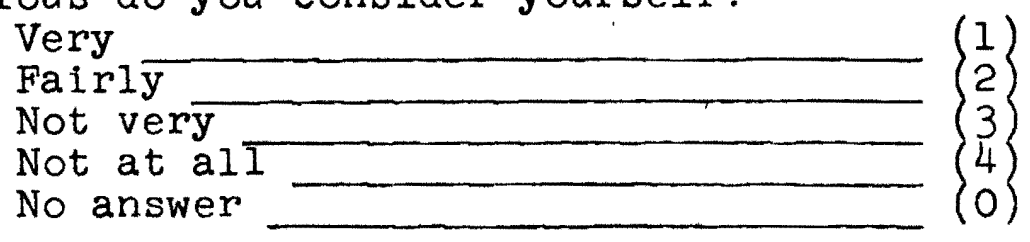

Please list other people living in household:

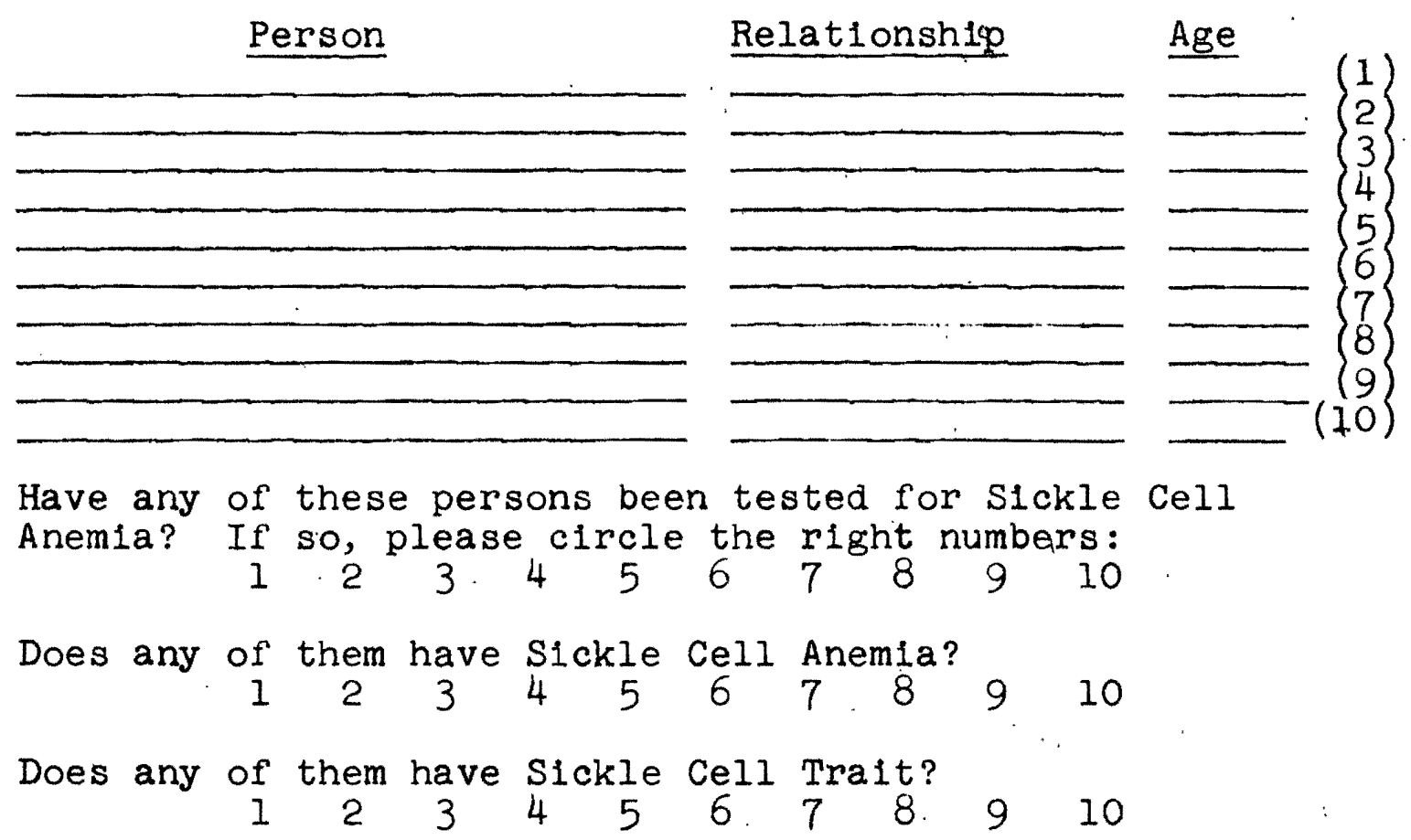


Living Arrangements of Patient:

Parents:

Both natural parents in home

Mother only in home

Father only in home

Mother and stepfather in home

Father and stepmother in home

Not living with parents

No answer

Other living arrangements:

With foster parents

With adoptive parents

In institution for children

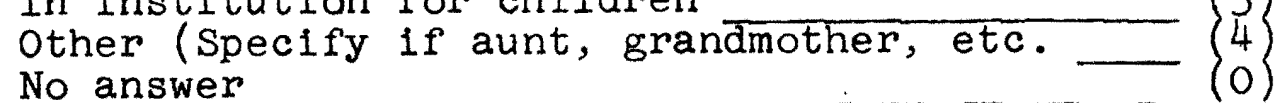

Section II. Clrcumstances Surrounding Your Awareness of Slckle Cell Anemia

When did you first learn of Sickle Cell Anemia?

From what source did you learn of Sickle Cell Anemia?

Doctor

Radio

Friend

Television

No answer

(1) Newspaper

School Scr

Agency

other

lease give a brief description of what happens when someone has Sickle Cell Anemia.

\section{Circumstances Surrounding Diagnosis:}

How long has it been since you learned that the patient had Sickle Cell Anemia?

Less than six months ago

7. months to 1 year

2 to 3 years

4 to 5 years

6 to 7 years

8 to 9 years

10 years or longer

No answer 
What was the age of the patient at that time?

What kind of symptoms caused you to take the patient to the hospital or doctor for the first time? Check any that apply.

$\left.\begin{array}{l}\text { Irritability } \\ \text { Vomiting } \\ \text { Fever } \\ \text { Pain in chest, back, stomach, etc. } \\ \text { Headache } \\ \text { Patient seemed more tired than others } \\ \text { of his age } \\ 3 \\ 4 \\ 5\end{array}\right)$

What was the age of the patient the first time he needed to go to the hospital or doctor for any of the symptoms given in the question?

Who accompanied the patient? (Specify)

How many times has the patient been hospltalized?

In the inftial contact for the above symptoms, were you given the diagnosis of sickle cell anemia? Yes (1) No (2) No answer If no, what was sa1d to be wrong with the patient? Please explain.

Section III. Counseling, Comprehension, and Reaction Counseling

Have you received any counseling since you found out that a member of your family has sickle cell anemia? Yes (1) No (2) No answer (0)

Please answer the following questions only if you recelved some type of counseling:

When did the counseling occur? Immediately following diagnosis of slckle cell anemia Less than one month following diagnosis From one month to six months following diagnosis 
Six months following diagnosis

No answer

Who in patient's family received counseling?

Who did the counseling?

Soclal worker

Doctor

Nurse

Person in screening clintc

Minister

Friend

Other

No answer

Did you find the counseling:

Helpful

Not heIpful

Can't remember

No answer

What do you remember from counseling? Please be as specific as possible.

Section IV. Reactions

When the patient was diagnosed as having SCA, did you seek the opinions of other doctors? Yes No (2) NA (0)

Did you believe the diagnosis was correct? Yes No _ (2) NA _ (0)

D1d you discuss the disease with any of the following people? Please circle the appropriate number:

The patient

Wife or husband

Grandparents

(1) Other children in

family

No answer

Friends
Other (spec1fy)

Did you tell the patient about SCA? Yes

No

(2)

NA

(0)

(1) 
If yes, how long after the initial diagnosis was made?

What did you tell the patient about his iliness? Specify

How well does he understand his 111 ness, in your opinion?

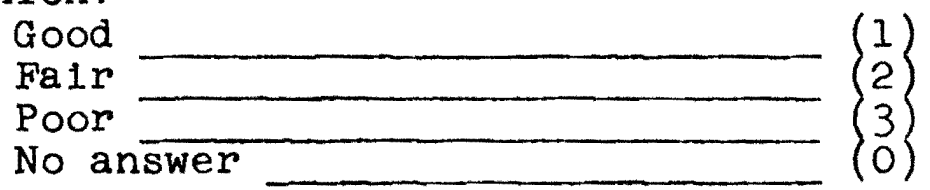

How well do you think the famliy understands the patient's iliness?

Good Fair Poor $\begin{aligned} & \text { Do not Have } \\ & \text { under- not dis- } \\ & \text { stand cussed }\end{aligned}$

Parents:

Brothers and

Sisters:

Grand-

parents :

other

members: 


\section{APPENDIX C \\ QUESTIONNAIRE FORM B}

SECTION I. IDENTIFYING DATA

Sex of Respondent Male (1) Female (2)

Age of Respondent

Marital Status:

Single
Married
Divorced-
Separated
Widowed
No answer

What is the highest grade completed in school?

$0-5$

$6-9$

$10-11$

High School Graduate

$1-3$ years of college

College graduate

No answer

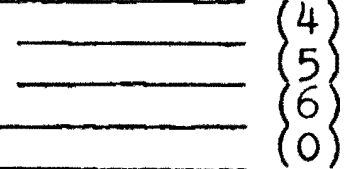

Are you currently employed? - Yes(1) No answer(0) $^{\text {No(2) }}$

If yes, what is your occupation?

If no, what is your source of income?

What is your approximate monthly income before taxes?

Less than $\$ 200$

$\$ 200$ to $\$ 299$

$\$ 300$ to $\$ 399$

$\$ 400$ tó $\$ 499$

$\$ 500$ to $\$ 599$

$\$ 600$ to $\$ 699$

$\$ 700$ to $\$ 799$

$\$ 800$ to $\$ 899$

$\$ 900$ or more

No answer

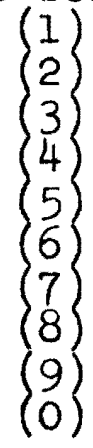


To what ethnic group do you belong?

Black
Mexican-American
White
Other (Specify)
No answer

To what religious group do you belong?

Protestant
Catholic
Jewish
Other (Specify)
No answer

SECTION II. AWARENESS OF SICKLE CELL DISEASE

Have you ever heard of sickle cell anemia? Yes(i) No(2) No answer(0)

Have you ever heard of sickle cell tralt? Yes(1) No(2) No answer(0)

If yes, from what source did you learn about sickle cell anemia and/or sickle cell trait?

$\left.\begin{array}{l}\text { Doctor } \\ \text { Radio } \\ \text { Friend } \\ \text { Television } \\ \text { Newspaper } \\ \text { School Screening Clinic } \\ \text { Agency (Specify) } \\ \text { Other (Specify) } \\ \text { No answer } \\ 4 \\ 5 \\ 6 \\ 7 \\ 8 \\ 0\end{array}\right)$

If yes to above question, how long ago did you learn about sickle cell anemia and/or sickle cell trait?

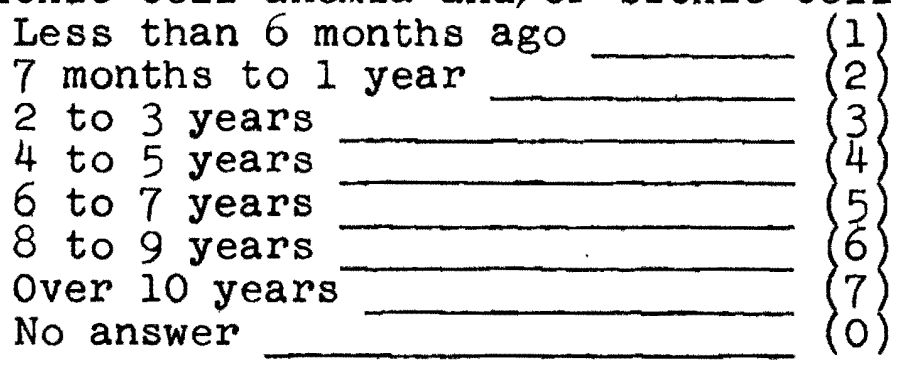

Please check the following items that best describe sickle cell anemia and/or sickle cell trait. 
Most people who have sickle cell anemia are under 20 years of age

Sickle cell anemia is a disease of the blood

People do not get sick when they have the sickle cell trait

Sickle cell anemia is a disease of the aged

Both sickle cell anemia and sickle cell trait are inherited

Sickle cell anemia is highly contagious

Sickle cell anemia is a very serious and often fatal disease

A person can have slckle cell trait and not know that they have $1 t$

Sickle cell anemia is caused by "wild" living

Sickle cell anemia is a disease that usually strikes black people

There is no cure for sickle cell anemla or sickle cell trait

A person can't catch slckle cell anemia like mumps or measles

A person is born with sickle cell anemia

A person is born with sickle cell trait

SECTION III.

Listed are some statements which some people agree and some disagree. Please state your opinions about the statements by checking the items and to what degree you agree on disagree. 
1. All people should be tested for hereditary disease. Strongly Agree Strongly Disagree Slightly Agree No Answer Slightly Disagree

2. Most parents care more about their healthy children than they do about their sick children. Strongly Agree Slightly Agree Strongly Disagree No Answer Slightly Disagree

3. People with sickle cell disease should not be allowed get married. Strongly Agree Strongly Disagree Slightly Agree No Answer

Slightly Disagree

4. It is a mother's duty to do her best to avold any disappointments for her children. Strongly Agree Strongly Disagree Slightly Agree No Answer Slightly Disagree

5. Most parents with sickle cell anemia children love them more than they love their other children Strongly Agree Slightly Agree Strongly Disagree No Answer Slightly Disagree

6. If a family member has sickle cell anemia or the sickle cell trait, it should be kept a secret. Strongly Agree Strongly Disagree Slightly Agree No Answer Slightly Disagree

7. Sometimes I feel that the sickle cell anemia subject is just one more example of white supremacy and the black man's burden. Strongly Agree Strongly Disagree Slightly Agree No Answer Slightly Disagree

8. Children with sickle cell anemia or sickle cell trait should not be allowed to play with those children who do not have sickle cell anemla or sickle cell trait. Strongly Agree Strongly Disagree Slightly Agree No Answer Slightly Disagree

9. The future is gloomy for the family with a member having sickle cell anemia.

Strongly Agree Strongly Disagree Slightly Agree No Answer Slightly Disagree

10. Most doctors don't know enough about sickle cell anemia and sickle cell trait.

Strongly Agree Strongly Disagree
Slightly Agree No Answer
Slightly Disagree 
11. Having a child with sickle cell anemia causes many problems in a marriage.

Strongly Agree Strongly Disagree

Slightly Agree No Answer

Slightiy Disagree

12. The family having a sick child faces unbearable financial hardships.

Strongly Agree

Strongly Disagree

SlightIy Agree No Answer

Slightly Disagree

13. All people regardless of race should be required by law to be tested for hereditary disease before they are allowed to marry.

Strongly Agree

Strongly Disagree

Slightly Agree No Answer

Slightly Disagree

14. Mass screening for sickle cell disease is being used to stop the growth of the black population. Strongly Agree Strongly Disagree Slightly Agree No Answer Slightly Disagree

15. People with sickle cell anemia should be sterilized. Strongly Agree Strongly Disagree Slightly Agree No Answer Slightly Disagree

16. A family is drawn closer together if someone in the family has sickle cell anemia. Strongly Agree Slightly Agree Strongly Disagree No Answer Slightly Disagree

17. Healthy brothers and sisters are cheated if a family member has sickle cell anemia. Strongly Agree Strongly Disagre Slightly Agree No Answer Slightly Disagree

18. Black people have no cholce in their life. Strongly Agree Strongly Disagree Slightly Agree No. Answer

SIlghtly Disagree

19. The name sickle cell anemia should be changed. Strongly Agree Strongly Disagree Slightly Agree No Answer Slightly Disagree

20. Sickle cell anemia means someone with bad blood. Strongly Agree Strongly Disagree Slightly Agree No Answer Slightly Disagree 
21. If sickle cell disease was found.predominantly among the white population, more research would have been done.

Strongly Agree Slightly Agree Strongly Disagree No Answer

Slightly Disagree

22. Having a child with sickle cell anemla is a disgrace to the family. Strongly Agree Strongly Disagree Slightly Agree No Answer Slightly Disagree

23. Public education about sickle cell anemia would help people plan and prepare for their own families. Strongly Agree Slightly Agree Strongly Disagree No Answer Slightly Disagree

24. The law should have no authority over a person's right to marry or have children.

Strongly Agree Strongly Disagree Slightly Agree No Answer

Slightly Disagree

25. Screening programs for sickle cell disease is necessaly for providing better health care and counseling services.

Strongly Agree Strongly Disagree Slightly Agree No Answer

Slightly Disagree

26. Parents should give more attention to their sick children because they have fewer opportunities to participate in normal childhood activities. Strongly Agree Slightly Agree Strongly Disagree No Answer Slightly Disagree

27. People having sickle cell trait should be prevented from having children. Strongly Agree Strongly Disagre Slightly Agree No Answer Slightly Disagree

28. Sickle cell anemia and sickle cell trait is being used by politicians to get votes. Strongly Agree Silghtly Agree Strongly Disagree No Answer Slightly Disagree 